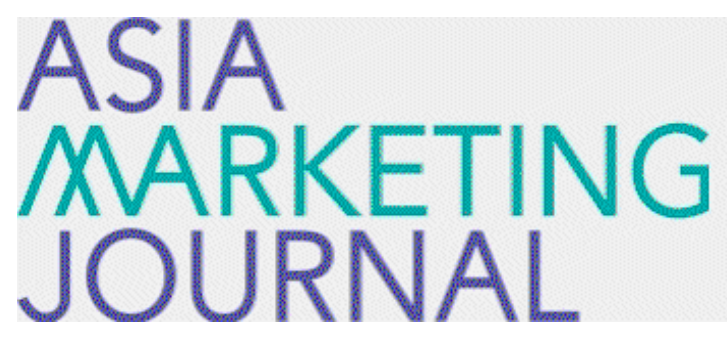

ASIA MARKETING JOURNAL

Volume 8 | Issue 1

Article 3

4-25-2006

\title{
디지털 환경에서 고객 참여를 톻한 고객 주도형 관계 구조 형성에 관한 탐색적 연구
}

Jong Won Lim

Suk Joon Yang

Follow this and additional works at: https://amj.kma.re.kr/journal

Part of the Marketing Commons

\section{Recommended Citation}

Lim, Jong Won and Yang, Suk Joon (2006) "디지털 환경에서 고객 참여를 톻한 고객 주도형 관계 구조 형성 에 관한 탐색적 연 구," Asia Marketing Journal: Vol. 8 : Iss. 1 , Article 3.

Available at: https://doi.org/10.53728/2765-6500.1161

This Article is brought to you for free and open access by Asia Marketing Journal. It has been accepted for inclusion in Asia Marketing Journal by an authorized editor of Asia Marketing Journal. 


\section{디지털 환경에서 고객 참여를 통한 고객 주도형 관계 구조 형성에 관한 탐색적 연구*}

\section{An Exploratory study on the Effect of Digital Environment on Customer Participation and Marketing System}

임 종 원 (Lim, Jong-Won) ${ }^{* *}$

양 석 준(Yang, Suk-Joon)***

디지털 환경이 보편화됨에 따라 고객들은 기업과의 관계에 있어서 보다 적극적이고 참여적으로 변 화하고 있다. 이에 따라 과거 산업 혁명 이후에 형성된 기업위주의 고객-기업 간의 관계가 깨지고 고 객들이 고객- 기업 간의 관계를 주도하는 현상들을 주변에서 쉽게 찾아볼 수 있게 되었다. 이에 본 연구에서는 고객이 주도하는 새로운 고객-기업간 관계구조의 형성 가능성에 대하여 디지털 환경을 중심으로 구체적으로 모델을 설정하고 실증을 통하여 그 가능성을 검토하였다.

연구의 결과 디지털 환경의 정보개방성, 연결성, 공동체 상호작용, 구조 명확성의 특성이 고객의 정 보 공유 의도에 영향을 미치는 것으로 나타났으며, 가상 커뮤니티를 기반으로 한 연구에서는 고객의 정보 공유로 인하여 축적된 제품 속성 정보와 소비 경험 정보가 집단 효능감을 매개로 고객들의 적 극적인 관계 구조 변화 노력인 리버스 마케팅에 영향을 미치는 것으로 나타났다. 따라서 디지털 환경 은 장기적으로 고객 주도적인 고객-기업 간의 관계가 형성될 수 있는 기반을 마련하여 주고 있다고 볼 수 있으며, 점차 고객-기업 간의 관계의 주도권은 고객으로 이전될 수 있음을 확인하였다. 또한, 향후 연구 과제로서 고객-기업 간 관계가 고객 주도적으로 변화한 이후의 마케팅 프로세스와 기업의 마케팅 시스템에 대한 연구가 필요함을 제안하고 있다.

핵심개념: 고객참여, 정보공유, 리버스마케팅. 소비자주도, 디지털 환경에서의 소비자행동

* 본 연구는 서울대학교 경영연구소의 지원으로 작성되었음.

** 서울대학교 경영대 교수(Jim@snu.ac.kr)

*** 경성대학교 경영학과 전임강사(handasol@chol.com) 


\section{I. 서 론}

산업 혁명 이전의 시대에 마케팅 측면에서 바 라본 고객과 기업 간의 관계구조는 고객이 주 도하는 관계구조였다고 할 수 있다. 대부분의 상품 생산이 고객의 주문에 의해서 시작되고. 맞춤형 생산으로 이루어졌다. 예를 들면 고객이 쟁기가 필요하면 대장간에 주문을 하고, 대장간 은 이러한 주문을 바탕으로 쟁기를 만들어 고. 객에게 주는 것이 고객과 기업 간의 관계였으 며. 이 관계를 시작하고 주도하는 것은 고객이 었다. 하지만, 산업 혁명에 의한 대량생산 체계 의 도입은 이러한 고객-기업 간의 관계를 완전 히 뒤바꾸는 역할을 하였다. 대량생산에 의한 획기적인 생산단가의 절감으로 인하여, 고객들 이 자신에게 정확하게 맞지 않는 제품을 구매 하여야 하는 불편에도 불구하고 그 저렴한 가 격으로 인하여 대량생산에 의한 제품이 시장의 주를 이루게 되었다. 따라서, 고객과 기업 간의 관계 또한 과거의 고객 주도적인 관계에서 기 업 주도적인 관계로 변화하게 되었다(Shrama and Sheth 2004).

기업 주도형 관계 형성이라는 것은 교환구조 라는 측면에서 살펴볼 때 여러 가지 비효율적 인 점을 가질 수 밖에 없다. 첫째, 고객들은 자 신들이 원하는 상품이 아니라 원하는 상품과 가장 유사한 상품을 구매하고 사용할 수 밖에 없게 되었다. 둘째, 대량 생산은 비용절감의 기 회도 크지만 고객 욕구와 맞지 않는 상품을 생 산한 경우 그에 따른 비용 손실도 매우 크다. 따라서, 기업들은 항상 신제품의 실패를 줄이기 위하여 고객들의 욕구 조사에 많은 비용을 소
모하게 되었으나 기업 주도적인 관계에서 비롯 된 교환구조의 특성상, 신상품의 실패는 매우 흔한 일이 되었다. 하지만 대량생산이 가져다준 비용 절감의 효과는 이러한 비효율적인 측면을 모두 상쇄할 정도로 컸기 때문에 기존의 대량 생산 시스템은 유지될 수 있었다.

하지만, 최근 디지털 환경이 보편화됨에 따라 기존의 기업 주도적 고객-기업 간의 관계에서 는 보기 어렵다고 생각되었던 현상들이 발생하 고 있음을 쉽게 발견할 수 있게 되었다. 예를 들면 과거의 고객들은 $\mathrm{TV}$ 드라마를 시청(소 비)할 때 재미있으면 시청을 계속하고 재미없 으면 시청을 그만두는 정도였지만, 디지털 인프 라를 자유롭게 사용할 수 있게된 현재의 고객 들은 드라마가 자신의 뜻에 맞지 않으면 시청 을 그만두는 것이 아니라 드라마의 내용을 자 신의 뜻에 맞게 고치도록 여러 가지 방법을 통 해서 압력을 가하는 모습을 흔히 볼 수 있게 되었다. 또한, 기업이나 제품에 대한 불만도 과 거에는 개인적인 불만 토로에 그치는 정도였으 나 이제는 인터넷 등을 통하여 집단적으로 기 업에 대응하고 있는 모습들을 쉽게 찾아볼 수 있게 되었다(민승규 2001).

이러한 현상들에 대하여 최근 많은 학자들은 기업과 고객과의 관계에서 고객의 역할이 과거 와는 다르게 변화하고 있음을 지적하고 있다. Hagel III and Armstrong(1997)은 디지털 환경 에서 고객이 정보의 주도권을 쥐고 기업을 이 끌어 나가는 형태인 역시장이 형성될 것임을 지적하고 있으며, 주우진과 김재범(2002)은 고 객이 생산자의 역할까지 대신하는 프로슈머로 변화하고 있음을 지적하고 있다. Seybold(2002) 는 과거의 기업이 아닌 고객이 주도적으로 마 
케팅 활동을 펼쳐나가는 고객 참여 현상에 대 하여 논하고 있다. Sharma and Sheth(2004)는 디지털 환경 하에서 고객이 주도적으로 마케팅 을 펼쳐 기업에 어떤 마케팅 제안을 하는 소비자 -기업 간의 리버스 마케팅(reverse marketing) 현상이 보편화 될 수 있음을 지적하고 있다. 이 렇게 학자들은 교환관계에 있어서 고객이 보다 적극적인 행동을 하는 주체로 변화하는 새로운 환경 속에서 기업은 그들의 마케팅 활동을 전 개해야 하는 상황에 놓이게 되었음을 지적하고 있다.

디지털 환경의 보편화에 따라 고객과 기업간 의 관계는 변화하고 있으며, 많은 학자들은 그 핵심적인 요인으로 고객 참여를 지적하고 있다 (임종원, 이동일 2002: 주우진, 김재범 2002; Wind and Rangaswamy 2000). 디지털 환경 하에서 활성화되고 있는 고객 참여의 현상들은 과거의 기업 주도적인 고객-기업 간의 관계가 새로운 고객 주도적 관계로 변화할 수 있는 가 능성을 보여주고 있다고 할 수 있다. 만약 이런 현상들이 확산된다면 기업에게 이는 새로운 기 회 혹은 위협 요인들이 될 뿐만 아니라, 학자들 에게는 지금까지 기업 주도적 관계 측면에서 연구되어 왔던 많은 연구들을 다시 돌아보아야 하는 계기가 될 수 있을 것이다.

하지만, 디지털 환경에서 고객의 다양한 참여 현상에 대한 연구는 부족한 편이며. 고객-기업 과의 관계구조의 변화가 어떤 과정을 통해서 일어나는 것인지, 또한 현재는 부분적으로 보이 고 있는 이러한 고객-기업 관계의 변화가 전 산업에 걸쳐서 심화될 것인지, 아니면 어떤 분 야를 중심으로 일어날 것인지를 밝힌 연구는 매우 찾아보기 어려운 편이다.
이에 본 연구에서는 디지털 환경에서 고객들 이 보다 적극적인 참여자로 변신하고 있는 이 유를 디지털 인프라 측면에서 검토해 보며, 고 객-기업 간의 관계에 있어서 고객의 관계 주도 적인 행동들이 어떤 과정을 거쳐 나타나는 것 인지를 검토해 보아 향후 고객 주도적 관계 형 성에 대한 연구의 기초를 다져보고자 한다. 또 한. 고객 주도적 관계가 형성되는 것에 따라 향 후 연구하여야 할 과제에 대하여도 논의하여 보고자 한다.

\section{II. 기업-고객 관계 구조의 변화 과정에 대한 이론적 고찰}

\section{1 디지털 환경의 도입과 고객 참여의 활성화}

디지털 환경의 도입 이후에 달라진 소비자 행 동의 특징 중 가장 두드러지는 측면은 "고 객 참여"라는 측면이라고 할 수 있다(Wind and Rangaswamy 2000: 임종원. 이동일 2002: 주우 진, 김재범 2002). 고객 참여란 고객의 적극적이 며 책임 있는 기업 활동에의 관여로(Bettencourt 1997), 고객들은 더 이상 기업과의 관계에 있어 서 수동적인 소비자로 남아있는 것이 아니라. 적극적으로 자신이 구매하고자 하는 상품에 대 한 정보를 기업에게 주려 한다든지. 기업에게 새로운 제안을 한다든지 혹은 다른 고객들에게 상품의 구입과 활용방법에 대한 여러 가지 정 보를 나누어 주어 다른 고객의 구매 활동에 영 향을 미치는 행위를 뜻한다. 
이러한 고객 참여는 과거 서비스 분야에 있어 서 주로 연구가 이루어져 왔다. Lovelock and Young(1979)이 미국의 경제 불황 시기에 서비 스 생산성을 혁신하는 하나의 방법으로 고객 참여를 제안한 이후로, 주로 생산성을 높이기 위한 측면에서 고객참여가 연구되었다. 고객 참 여를 주로 연구한 학자들은 고객 참여를 통하여 생산성 향상(Mills, Chase, and Margulies 1983; Fitzsimmons 1985), 고객 만족(Miller and Monge 1986), 제품 차별화(Song and Adams 1993)등 의 호과가 있을 수 있음을 주장하기도 하였다.

이렇듯 과거에도 고객 참여에 대한 관심과 연 구가 없었던 것은 아니지만, 고객 참여의 예상 된 성과에도 불구하고 오프라인에서 고객 참여 를 활발하게 활용하는 기업이나 적극적으로 참 여하는 고객들의 모습은 매우 제한적이었다. 그 러나, 이러한 과거의 모습에 반하여 디지털 환 경 하에서 일어나고 있는 고객 참여는 매우 폭 발적으로 증가하고 있으며, 참여의 범위와 정도 도 과거와는 비교할 수 없을 정도로 확대되고 있음을 발견할 수 있다(이두희 1999).

디지털 환경 속에서 고객이 적극적인 참여자 로 바뀌었다는 지적은 디지털 환경이 도입되기 전에는 고객들의 참여 행위가 많이 일어나지 않았다는 것과 일맥 상통한다. 왜 디지털 환경 이전에는 고객 참여가 많이 일어나지 않았는 가? 이것은 고객 참여의 전제 조건에 대한 과 거의 연구를 살펴봄으로써 참여가 소극적이었 던 이유를 설명할 수 있다.

기존 연구를 살펴볼 때 고객 참여가 고객과 기업 모두의 성과가 되기 위해서는 다음과 같 은 세 가지 전제조건이 필요함을 알 수 있다. 첫째. 고객들의 참여가 고객들이 인지할 수 있
을 정도의 혜택을 고객에게 줄 수 있어야 한다 (Fitzsimmons 1985; Mills and Morris 1986; Bowen and Jones 1986). 둘째, 고객이 자신의 역할이 무엇인지 명확하게 인식하도록 하여야 한다. 고객과 기업의 역할이 모호해지는 경우 고객 참여가 일어나기도 어렵고, 고객 참여가 상호간의 좋은 성과로 결실을 맺기는 어렵다 (Mills and Morris 1986; Lovelock and Young 1979; Song and Adams 1993). 셋째, 참여하는 고객은 참여에 필요한 적절한 지식을 보유할 필요성이 있다(Goodwin 1988: Song and Adams 1993).

과거 디지털 인프라가 부족했던 상황에서는 고객 참여가 성과로 이루어지기 위한 전제조건 을 해결하기 어려웠다. 첫째, 고객 참여로 인한 명확한 비용 대비 혜택을 고객에게 제시하기 어려웠다. 제조업을 생각해 본다면 기존의 오프 라인 상에서의 고객 참여는 대부분 판매 접점 에서 일회적으로 일어날 수밖에 없기 때문에, 상품을 제조하는 전체 프로세스와 비교해 볼 때 매우 적은 분야만 고객이 참여할 수 있었다. 따라서. 고객과의 상호작용이 풍부할 수밖에 없 는 서비스 산업을 제외하고는 고객의 참여활동 에 대해서 제대로 보상을 해주기 어려웠다.

둘째, 고객이 직원들과의 역할 충돌이 없이 기업이 기대한 참여 역할을 충분히 수행하도록 업무의 프로세스를 짜는 것은 기존의 오프라인 상에서는 매우 어려운 일이 될 수 있다. 오프라 인 상에서는 고객들의 돌발행동이나 혹은 충분 하지 못한 참여를 효과적으로 통제할 수 있는 수단이 많지 않기 때문이다. 이러한 어려움에 대하여 Biter et al.(1997), Bowen and Jones (1986)등은 고객 참여가 서비스 불안정성을 높 
이는 원인이 되기 때문에 고객 참여를 최소화 할 수 있는 시스템을 설계할 것을 권하기도 하 는 등 고객의 적절한 역할 수행에 대한 통제는 오프라인의 매우 큰 어려움으로 남아 있었다.

셋째, 디지털 인프라가 구축되기 전에는 고객 들에게 수행하여야 하는 역할에 대한 지식을 알려주는 것은 매우 많은 비용이 소요되었다. 고객 교육을 위해서는 서비스 접점의 직원들이 직접 고객에게 적절한 지식을 알려주거나, 혹은 고객들이 책자 등을 통하여 공부해야 했다. 하 지만, 1 회적-거래적 관계가 주된 고객-기업 간 의 관계를 형성할 수밖에 없었던 디지털 인프 라 구축 이전의 시대에 있어서 이러한 참여의 방법에 대한 지식 교육은 고객과 기업 모두 성 과에 비하여 너무 많은 비용을 수반할 수밖에 없었다는 한계를 가질 수밖에 없었다.

그러나 과거의 비디지털 환경에서 제기되었던 참여의 성과 창출을 가로막는 장벽에 대한 문 제에 대하여 디지털 환경은 새로운 해결책을 제시할 수 있게 되었다. 첫째, 과거에 서비스 접점에서만 일어나던 고객 참여를 이제는 기업 의 전부서로 확대할 수 있게 되면서, 과거의 서 비스 접점에서 할 수 있었던 것보다 고객에게 보다 충분한 혜택을 줄 수 있는 환경이 조성되 었다. 예를 들어 과거에는 소포가 예정된 시간 에 도착하지 않은 경우 보통 소포를 맡긴 곳에 전화를 해서 물어보면 서비스 접점에 있는 담 당직원이 소포의 현재 위치를 확인해서 응답을 하여 줄 수밖에 없었다. 그러나. 디지털 환경의 도입으로 인하여 고객은 인터넷에서 소포 번호 만 입력하면 언제 어디서나 소포의 현재 위치 를 확인할 수 있게 되어, 기존에 소모되었던 많 은 시간과 비용을 절감하면서도 고객에게 편리
를 제공하여 줄 수 있게 되었다. 둘째, 웹사이 트 등의 구조를 잘 꾸밈으로써 고객의 역할을 보다 분명하게 알려줄 수 있게 되었다(Watson et al. 2000). 예를 들어 과거에는 주문서에 전 화번호나 우편번호를 잘못 입력하는 경우 제품 을 배달 받을 수 없거나 배송이 매우 늦어졌지 만, 지금은 인터넷에서 전화번호나 우편번호를 잘못 입력하는 경우 즉시 잘못 입력했다는 경 고를 고객에게 보내어 올바른 번호를 입력할 수 있도록 도와준다. 셋째. 고객 참여 방법에 대한 지식을 웹사이트와 커뮤니티를 통하여 쉽 게 취득할 수 있게 되었다. 특히. 커뮤니티의 부상은 효과적인 고객 참여를 끌어내는데 큰 역할을 하였다. 고객들은 이러한 가상 커뮤니티 의 구축을 통하여 빠르게 정보를 교환하고 이 를 통하여 스스로의 지식수준을 높여 고객 참 여의 방법을 보다 쉅게 깨닫게 되었으며. 수요 를 집적화 시킬 수 있게 됨에 따라서 고객 참 여의 성과를 보다 크게 할 수 있었다(강명수 2002: Newman 2003).

새롭게 도입된 디지털 환경의 영향으로 고객 돌은 다양한 방법으로 기업의 마케팅 프로세스 에 참여함으로써 여러 가지 혜택을 누리는데 익숙해져 가고 있다. 고객들은 기업의 사이트에 스스로 접근하여 불만과 만족을 토로하고, 기업 의 사이트나 제품 관련 공동체의 여러 가지 지 식을 공부하고 자신이 가진 정보를 다른 사람 들에게 제공하는 것을 점차 당연시 여기고 있 으며, 이러한 활동들은 시간과 장소의 제약을 넘어 24시간 소비자의 위치와 상관없이 일어나 고 있다(이두희 1999: Merrilees and Miller 2001: Sharma and Sheth 2004). 


\section{2 축적된 정보를 통한 고객의 관계 주도 행위의 증가}

디지털 환경이 보편화되면서 가상공간에서 소 비자들의 마케팅활동에 대한 참여가 아주 유용 하고 편리하게 되었다. 디지털의 특성상 초기 의 참여는 여러 참여형태 중 정보의 공유가 가 장 보편적인 형태로 지적되었다(임종원, 이동일 2002; 김현식 2004). 디지털 환경의 초기에는 이러한 참여는 인터넷의 정보 제공 사이트 가 입시 소비자 개인의 정보를 제공해야 하는 것 처럼 대개 기업이 고객의 참여를 유도하는 형 태였으며, 개별 소비자들의 참여를 유도하는 형 태였다고 볼 수 있다. 또한, 초기 소비자들은 자신의 정보 제공을 단순히 다른 정보를 얻기 위한 하나의 단순한 방편으로 생각하고 있는 일시적 형태로 바라볼 수 있다. 그러나, 보다 디지털 환경이 확대되면서 다양한 고객 참여의 형태가 나타나게 된다.

고객들은 디지털 환경, 특히 인터넷을 통하여 기업에 자신의 신상 정보를 제공할 뿐만 아니 라. 자신이 가지고 있는 제품에 대한 다양한 정 보나 혹은 제품 사용 경험 등을 제공하여 서로 공유하기 시작하였다. 일부 포털 기업들은 이를 활용하여 지식 검색 서비스 등을 제공하여 고 객들의 다양한 정보를 자신의 자산으로 활용하 기도 하였다. 또한 고객들이 공동체(community) 를 조직하여 제품에 대한 평가와 각종 정보를 교환하는 인터넷 구전활동(words of mouth by internet)도 활발하게 수행하는 모습을 볼 수 있다(이은영 2004).

디지털 환경 속에서 고객의 이러한 정보 공유 행위의 결과는 과거의 아날로그 환경과는 다른
결과를 가져오게 된다. 첫째 과거 구전 등 일반 적인 개인이 생산한 정보의 전파가 비분리성을 지넜던 것에 반하여 디지털 환경 내에서는 개 인이 생산한 정보라도 인터넷 사이트 등을 통 해서 축적되는 것이 가능해 졌으며, 둘째 이러 한 정보들을 쉽게 다른 사이트로 복사하는 것 이 매우 쉬워졌으며, 셋째 고객들은 이러한 정 보를 검색엔진 등을 통하여 쉽게 찾아볼 수 있 게 되었다(이은영 2004).

디지털 환경 내에서 활성화되고 있는 커뮤니 티의 부상 또한 고객들의 정보력을 높이는 데 에 큰 기여를 하게 된다. 어떠한 제품이나 주제 를 대상으로 하는 커뮤니티를 통한 고객들간의 활발한 정보교환 활동들로 인하여 고객들은 기 업과 동등하거나, 제품의 소비 경험에 있어서는 기업의 담당자보다 더 많은 정보를 접할 수 있 게 되었다(Newman 2003; 강명수 2002).

일련의 디지털 환경에 의한 변화들로 인하여 고객들의 정보 수준은 비약적으로 향상되었다. 이제 제품을 구매하거나 사용할 때 고객들이 해당 제품을 제조한 기업의 사이트나 혹은 해 당 제품과 관련된 소비자 커뮤니티를 통하여 제품의 사용에 관련한 노하우(know-how)를 얻 는 것은 보편화되었으며, 이러한 정보를 기반으 로 고객들은 보다 합리적인 의사결정을 할 수 있게 되었다(Berthon and Pitt 1996).

고객들의 정보 수준의 향상은 고객의 행동에 변화를 일으키는 하나의 계기가 되었다(이은영 2004: Biemans and Brand 1995). 정보수준의 향상으로 인하여 고객 스스로 지각하는 파워가 증가되며, 이에 따라 고객은 자신에게 유리한 제 품을 구매하기 위하여 보다 적극적으로 노력하 게 되었다(Glazer 1991; Berthon and Pitt 1996). 
이렇게 고객이 정보의 주도권을 쥐고 기업 을 이끌어 나가는 형태의 시장을 Hagel III and Armstrong(1997)은 역시장(reverse market)이 라고 지적하였으며, Leenders and Blenkhorn (1988)은 산업재 시장에 대한 연구에서 유리한 제품의 구매를 위하여 노력하는 고객의 활동을 리버스 마케팅(reverse marketing)이라고 명명 하기도 하였다.

리버스 마케팅은 구매자가 관계의 주도권을 가지고 판매자의 마케팅 활동을 이끌어 나가는 행위이다(Choi 1999: Leenders and Blenkhorn 1988). 그러나, 디지털 환경과 온라인 커뮤니티 가 도입되기 전까지는 대량 생산 체계 속에서 구매량이 적은 일반 개인 고객으로서는 그가 아무리 적극적이라 할 지라도 리버스 마케팅 활동은 거의 불가능한 일일 수 밖에 없었다. 따 라서, 디지털 환경 이전의 리버스 마케팅 개념 은 산업재의 영역에 머무를 수밖에 없었다. 하 지만, 디지털 환경과 온라인 커뮤니티가 보편화 되면서 고객들이 각각의 구매 정보들 조직하여 공동구매를 하거나, 커뮤니티를 통하여 집단 구 매력을 형성하고 이를 통하여 공급자를 선택하 는 역경매(reverse auction)까지 발전하고 있는 현상은 흔히 볼 수 있는 현상이 되었다(이동일 2000). 이렇듯 디지털 환경 속에서 이제 최종 소비자들은 향상된 정보수준과 디지털 인프라 의 다양한 정보에 대한 믿음을 바탕으로. 보다 집단화된 소비자들이 주도하는 고객 참여를 시 행할 수 있게 되었다. 이러한 배경을 바탕으로 보다 장기적인 관점에서 기업과 관계를 맺고. 또 그 관계를 주도하며 기업의 생산과 판매과 정을 자신에게 유리하도록 변화시키려 하고 있 다. 이에 대하여 Sharma and Sheth(2004)는
기업도 이제 일반 소비자와의 관계에 있어 고 객들의 리버스 마케팅 활동을 활용하여야 함을 주장하고 있다.

\section{III. 실증 연구1: 고객 정보 공유 의도에 영향을 미치는 디지털 환경 요인에 대한 연구}

\section{1 연구 가설의 설정}

본 연구에서는 고객 참여를 소극적 형태의 고 객 참여라고 할 수 있는 정보 공유와 적극적 형태의 고객 참여라고 볼 수 있는 리버스 마 케텅 (Sharma and Sheth 2004: Choi 1999: Biemans and Brand 1995)을 중심으로 연구를 진행하고자 한다.

고객 참여의 한 측면인 정보 공유는 고객이 기업의 마케팅 활동에 대한 반응으로 조직에 정보를 기여하거나. 다른 고객을 위해서 정보를 공유하는 고객의 행위를 뜻한다. 이는 기업을 주도하기보다는 주로 기업의 주도로 기업과 헙 력하기 위해서. 혹은 기업의 마케팅 활동에 대 한 불만을 표출하기 위해서, 혹은 다른 고객들 을 돕기 위해서 주로 사용된다고 볼 수 있어 (Zeithamal and Bitner 1997; Harrie et al. 2001; 이은영 2004) 소극적 형태의 고객 참여 활동으 로 분류할 수 있다.

이러한 정보 공유는 디지털 환경이 도입되기 이전부터 고객 참여의 중요한 요인으로 지적되 어 왔으며(Kellog et al 1997: Zeithamal and Bitner 1996: Larsson and Bowen 1989), 특히 
정보적 연결이 보편화된 디지털 환경에서 가장 많은 고객들이 사용하고 있는 고객 참여의 형태 로서 기업 성과를 높이는 주요한 변수로 연구되 었다(김현식 2004; Yao et al, 2005). 학자들은 고객의 자발적인 정보 제공을 기업이 잘 활용 할 수 있다면 기업의 성과에 매우 긍정적인 영향을 미칠 수 있을 것이며, 고객 참여의 맥 락에서 고객이 제공한 정보를 기업이 소중하 고 효율적으로 사용해야 함을 지적하고 있다 (Thomke and Hippel 2002; Keh and Teo 2001). 그러나. 소비자들의 보다 적극적인 리버스 마 케팅 활동은 단순히 디지털 환경만을 배경으 로 하지는 않는다고 볼 수 있다. 리버스 마케 팅이 소비자가 아닌 기존의 산업재 시장에서 주로 연구된 이유는 리버스 마케팅은 공급망 을 좌우할 정도의 많은 양의 구매, 높은 수준 의 교육 수준을 전제로 하기 때문이다(Leenders and Blenkhorn 1988; Biemans and Brand 1995). 따라서 정보 공유가 디지털 환경의 영향 에서 이루어 젔다는 가정을 할 수 있다면 리버 스 마케팅은 디지털 환경과 커뮤니티를 전제로 하여 이루어졌다고 할 수 있다.

본 연구에서는 배경이 다를 수 밖에 없는 고 객들의 정보 공유와 리버스 마케팅 활동을 분 리하여 모형화 하고자 한다. 첫 번째 실증 연구 에서는 고객들의 정보 공유 활동에 영항을 미 치는 디지털 환경 요인을 찾아보고자 하며, 두 번째 실증 연구에서는 고객들의 리버스 마케팅 에 영향을 미치는 디지털 환경에서의 가상 커 뮤니티를 전제로 커뮤니티 내의 리버스 마케팅 에 대한 영향 요인을 찾아보고자 한다.

실증 연구1에서는 먼저 소극적 고객 참여 행 동이라고 볼 수 있는 정보 공유에 영향을 미치
는 디지털 환경 특성에 대해서 먼저 살펴보고 자 한다.

첫 번째로 디지털 환경의 정보 개방성(information openness)을 들 수 있다. 조호현(1996) 은 정보에 대한 개방성을 디지털 인프라가 제 공해 주는 관계 특성임을 지적하였다. 정보개방 성은 디지털 환경의 도입으로 인하여 많은 정 보들이 쉽게 고객들에게 개방될 수 있음을 뜻 한다. 참여를 기업과 개인과의 관계라는 측면에 서 살펴볼 때 기업과 고객의 상호간의 정보의 개방성은 과거보다 깊은 폭의 참여를 가능하게 하여주는 요인이 될 수 있으며. 기업과 고객은 디지털 인프라의 정보 개방성적 특성 때문에 보다 최신의 정보를 정확하게 상호간에 전달 하여 주는 것이 가능해졌다(이문규 2002; 조호 현 1996). 이러한 정보 개방의 결과 고객들은 보다 충분한 혜택을 받을 수 있음을 인식하고 적극적으로 자신의 정보를 공유하는 것이 가능 해 졌으며, 어떠한 정보를 공유하는 것이 적절 한지에 대한 지식을 가지는 것이 가능해 졌다 (Fizsimmon 1985; 이문규 2002).

가설 1: 정보 개방성이 높을 수록 정보 공유 의도는 높아질 것이다.

두 번째로 연결성(connectedness)을 통하여 고객은 보다 폭넓은 마케팅 활동에의 참여가 가능해 졌음을 들 수 있다. 연결성은 고객들이 쉽게 디지털 인프라에 접근할 수 있는지에 대 한 심리적인 연결의 편의성. 즉 언제 어디에서 나 기업과 연결되어 응답 받을 수 있음을 뜻한 다(Memon et al. 1997). 이러한 연결성을 통하 여 고객들은 언제 어디서나 정보를 기업과 교 
환할 수 있게 되며(이태민 2003), 이를 통하여 고객들은 언제 어디서나 정보 공유에 대한 혜 택을 받을 수 있게 되었음을 지각할 수 있게 되었다. 따라서, 이러한 연결성은 고객에게 충 분한 참여의 혜택을 제시할 수 없었던 오프라 인에서의 참여의 제약 요인을 극복할 수 있어, 소극적 고객 참여 활동인 정보 공유를 활성화시 킬 수 있는 주요한 요인이 될 수 있을 것이다.

가설 2: 연결성이 높을수록 정보 공유 의도는 높아질 것이다

세 번째로 커뮤니티 상호작용성(community interaction)을 통하여 고객은 보다 참여에 대한 높은 지식을 얻을 수 있으며, 다른 고객들의 참 여하는 모습을 보며 자신의 역할을 보다 분명 히 할 수 있었음을 지적할 수 있다. 온라인 커 뮤니티는 고객 참여에 있어서 긍정적인 효과를 낳을 수 있을 뿐만 아니라 고객의 다양한 욕구 를 충족시킬 수 있는 서비스이기도 하다. 고객
들은 이러한 커뮤니티 상호작용을 통해서 타인 의 경험을 제공받아 보다 폭넓은 정보를 취할 수 있기도 하며(Holland and Baker 2001), 커 뮤니티 내의 다른 사람들의 행동을 본받아 자 신의 역할을 빠르게 습득하게 되어(Goodwin 1988), 보다 원활하게 정보 공유 활동에 참여할 수 있게 되었다.

가설 3: 커뮤니티 상호작용성이 높을수록 정 보 공유 의도는 높아질 것이다

마지막으로 구조 명확성(structure clarity)을 지적할 수 있다. 구조 명확성은 기존에 논의되 었던 역할 명확성을 디지털 인프라의 입장에서 본 개념이다. 구조 명확성은 고객들에게 자신의 역할을 명확하게 알려줄 수 있는 웹사이트의 기계적 상호작용의 특성에 기인한 것이다. 과거 의 연구를 살펴볼 때 고객의 역할을 명확하게 하는 것이 참여의 긍정적인 성과를 이끌어 내 는데 많은 영향을 미치고 있음을 살펴볼 수

〈표 1〉 고객 참여를 활성화 시켜주는 디지털 환경 요인

\begin{tabular}{|c|c|}
\hline $\begin{array}{c}\text { 고객참여 } \\
\text { 활성화 전제조건 }\end{array}$ & 디지털 환경 요인 \\
\hline $\begin{array}{l}\text { 고객에게 참여의 } \\
\text { 충분한 혜택 제시 }\end{array}$ & $\begin{array}{c}\text { 연결성: 언제나 기업과 연결되어 혜택을 받을 수 있음(Memon et al. 1997) } \\
\text { 유용한 참여 정보를 상호작용적으로 제공 받을 수 있음(이태민 2003) } \\
\text { 정보개방성: 충분한 혜택에 대한 인식 부여 가능(Fizsimmons 1985) } \\
\text { 높은 혜택을 받을 수 있는 깊은 참여가 가능(조호현 1996) }\end{array}$ \\
\hline 고객 역할 명확화 & $\begin{array}{c}\text { 구조명확성: 디지털 환경은 소비자 행동을 가이드해 주는 것이 가능(Watson et al. 2000) } \\
\text { 커뮤니티 상호작용: 커뮤니티 게시판 등을 통하여 타인 행동에 대한 기록 통하여 빠른 } \\
\text { 고객 참여의 역할 습득 가능(Goodwin 1988) }\end{array}$ \\
\hline $\begin{array}{l}\text { 참여에 필요한 } \\
\text { 적절한 지식의 } \\
\quad \text { 보유 }\end{array}$ & $\begin{aligned} \text { 커뮤니티 상호작용: } & \text { 타인 경험 등을 제공받을 수 있음(Holland and Baker 2001) } \\
& \text { 자신이 속한 집단 구성원들의 행동을 엿보는 것이 역할 수행에 가장 } \\
& \text { 큰 도움이 될 수 있음(Goodwin 1988) }\end{aligned}$ \\
\hline
\end{tabular}


있다(Bowen 1986: Larsson and Bowen 1989: Harris et al. 2001). 디지털 환경은 이러한 문제 를 컴퓨터의 기계적 상호작용을 통하여 해결할 수 있다. 컴퓨터는 고객들의 행동을 자동적으로 안내해 주는 것이 가능하다(Watson et al. 2000). 이러한 구조 명확성으로 인하여 고객들은 보다 편리하게 자신의 정보를 나누어주는 정보 공유 활동을 할 수 있게 되었다고 볼 수 있다.

가설 4: 구조명확성이 높을수록 정보 공유 의 도는 높아질 것이다.

이러한 가설과 이론적 고찰부분에서 요약한 고객 참여 활성화의 전제 조건을 연결하여 도 시하면〈표 1〉과 같다.

\section{2 구성개념의 조작적 정의 및 측정}

\subsection{1 정보 개방성}

본 연구에서는 디지털 인프라 특성 요인이라 는 맥락에 따라 정보 개방성을 '기업이 타기관 혹은 고객을 위하여 자사의 내부 정보를 제공하 는 정도로 조작적으로 정의하였다. 측정 항목은 조호현(1996)의 연구와 김학윤, 이호배(2001)의 연구를 바탕으로 하여 "디지털 인프라를 통하 여 관련 정보를 충분히 제공하고 있는 정도”, "디지털 인프라를 통하여 관련 정보를 정확히 제공하고 있는 정도". "디지털 인프라를 통하여 관련정보를 명확하게 제공하고 있는 정도"의 3 개 항목을 리커드형 7 점 척도 $(1=$ 전혀 그렇지 않다, $4=$ 보통이다, $7=$ 확실히 그렇다)로 측정 하였다.

\subsection{2 연결성}

본 연구에서는 디지털 인프라 특성이라는 맥 락에 따라 연결성을 심리적인 측면을 중심으로 "디지털 인프라를 통한 고객-기업 간의 정보교 환의 신속성 정도"로 조작적으로 정의하였다. 측정항목은 송창석(1996)과 Menon et al.(1997) 의 연구를 바탕으로 하여 "이용 과정 불만에 대한 운영자의 신속한 응답 정도", "이용자의 의견에 대한 운영자의 신속한 응답 정도”. “이 용자의 불만에 대한 운영자의 신속한 해결 정 도"의 3 개 항목을 리커드형 7 점 척도 $(1=$ 전혀 그렇지 않다, $4=$ 보통이다. $7=$ 확실히 그렇다) 로 측정하였다.

\subsection{3 커뮤니티 상호작용성}

본 연구에서는 커뮤니티 상호작용성을 "디지 털 인프라를 공동 이용하는 고객간, 혹은 고객기업 간의 정보 및 의견 교환의 정도”로 조작 적으로 정의하였다. 측정항목은 이문규(2002)의 연구와 이은영(2004)의 연구를 바탕으로 하여 "디지털 인프라 이용자들 간의 정보 교환의 용 이성 정도", "이용자들 간의 커뮤니터를 통한 교류의 용이성 정도", "이용자에 의한 게시물의 양이 많은 정도”의 3 개 항목을 리커드형 7점 척도 $(1=$ 전혀 그렇지 않다, $4=$ 보통이다, $7=$ 확 실히 그렇다)로 측정하였다.

\subsection{4 구조 명확성}

본 연구에서는 디지털 인프라 톡성 요인으로 서의 구조 명확성을 "고객이 명확하게 자신이 
해야 하는 행동을 인지할 수 있는지에 대한 디 지털 인프라의 디자인 정도"로 조작적으로 정 의하였다. 측정 항목은 임홍(2004)의 연구를 바 탕으로 하여 "일반 이용자가 하는 일과 운영자 의 일의 구분 정도., “일반 이용자들이 할 수 있는 역할의 구분 가능성 정도”. “일반 이용자 역할의 적정성 정도”의 3 개 항목을 리커드형 7 점 척도 $(1=$ 전혀 그렇지 않다. $4=$ 보통이다. 7 $=$ 확실히 그렇다)로 측정하였다.

\section{2 .5 정보 공유 의도}

본 연구에서는 고객 참여 행동의 한 형태로서 고객의 정보 공유에 대한 의도를 "기업의 마케 팅 활동에 대한 평가/자신의 정보 등을 디지털 환경을 통하여 공유하려는 의도”로 조작적으로 정의한다. 측정 항목은 Bettencourt(1997)의 연 구를 바탕으로 하여 "제품/서비스에 대한 아이 디어의 게시 의도", "활용 경헙에 대한 게시 의 도”, “홈페이지 이용 불편 정보의 게시 의도”의 3 개 항목을 리커드형 7 점 척도 $(1=$ 전혀 그렇지 않다, $4=$ 보통이다, 7 =확실히 그렇다)로 측정 하였다.

\section{3 조사대상 및 자료수집}

실증연구를 위한 조사 대상 표본은 디지털 인 프라 환경에서 선도적인 소비자 행동을 보이고 있는 20대 중심의 대학생 및 대학원생. 직장인 을 중심으로 조사대상을 선정하였다. 설문의 대 상은 쇼핑몰, 제조업체 관련 웹사이트, 정보제 공 관련 웹사이트 유형 중 최근 방문한 웹사이 트를 하나 선정하여 응답하도록 하였다. 설문지
는 총 468부가 배부되었고 그중 368 부의 설문 지가 회수되었다. 이들 가운데서 응답이 부실한 표본 15 개를 제외하고 총 353 개의 표본을 최종 분석에 사용하였다.

\section{4 표본의 일반적 특성}

총 351 명의 응답자 중 남성은 156 명 $(44.2 \%)$. 여성은 195 명 $(55.2 \%)$, 미응답 2명 $(0.6 \%)$ 으로 구성되었다. 응답자의 연령은 18 45세까지 분 포하였으나 이 중 $86.4 \%$ 가 20대였다.

응답자의 웹사이트 방문 경험은 월평균 14.5 회 였으며, 응답자 중 242 명 $(68.8 \%)$ 이 쇼핑 몰을 대상으로 응답하였으며 응답자중 111명 $(31.2 \%)$ 은 제조업체나 기타 운영 주체의 정보 제공 웹사이트를 중심으로 응답이 이루어 졌다.

\section{5 척도의 신뢰성 및 타당성 검증}

\subsection{1 신뢰도 검증}

신뢰성과 타당성의 개괄적 판단을 위해 요인 분석과 Cronbach-a 계수의 측정을 통하여 신뢰 도를 분석하였다. 분석 결과는 〈표 2〉와 같다.

본 연구에서 측정된 이론변수들은 Cronbach-a 계수값이 모두 0.8 이상으로 나타나 측정항목들 이 비교적 신뢰할 만한 수준에서 측정되었다고 볼 수 있다(Nunally 1967).

\section{5 .2 척도의 타당성 검증}

판별 타당성을 확인하기 위하여 확인적 요인 분석을 실시하였으며, 수렴 타당성의 판단을 위 
〈표 2〉디지털 환경 요인의 탐험적 요인 분석 및 신뢰성 분석 결과

\begin{tabular}{|c|c|c|c|c|c|c|c|c|}
\hline 구성개념 & 측정항목 & 요인1 & 요인2 & 요인3 & 요인4 & 요인5 & $\begin{array}{l}\text { Alpha } \\
\text { 계수 }\end{array}$ & $\begin{array}{c}\text { 설명된 } \\
\text { 분산의 } \\
\text { 비율 }\end{array}$ \\
\hline \multirow{3}{*}{$\begin{array}{c}\text { 정보 } \\
\text { 개방성 }\end{array}$} & 관련 정보를 충분히 제공 & .818 & .228 & .194 & .174 & .141 & \multirow{3}{*}{.8808} & \multirow{15}{*}{$\begin{array}{c}81.587 \\
\%\end{array}$} \\
\hline & 관련 정보를 정확히 제공 & .852 & .249 & .175 & .149 & .159 & & \\
\hline & 관련 정보를 명확하게 제공 & .778 & .161 & .189 & .185 & .240 & & \\
\hline \multirow{3}{*}{ 연결성 } & 이용 불만에 운영자 신속 응답 & .165 & .887 & .128 & .146 & .167 & \multirow{3}{*}{.9120} & \\
\hline & 의견에 운영자 신속 응답 & .202 & .898 & .071 & .115 & .170 & & \\
\hline & 제품 불만에 운영자 신속 해결 & .206 & .841 & .087 & .105 & .108 & & \\
\hline \multirow{3}{*}{$\begin{array}{l}\text { 커뮤니티 } \\
\text { 상호작용 }\end{array}$} & 이용자간 정보 교환 용이성 & .231 & .113 & .819 & .189 & .174 & \multirow{3}{*}{.8646} & \\
\hline & 이용자간 교류 용이성 & .206 & .105 & .867 & 189 & .138 & & \\
\hline & 커뮤니티 내부 게시물의 양 & .094 & .072 & .795 & .215 & .143 & & \\
\hline \multirow{3}{*}{$\begin{array}{c}\text { 구조 } \\
\text { 명확성 }\end{array}$} & 이용자 역할의 명확성 & .156 & .134 & .293 & .818 & .106 & \multirow{3}{*}{.8906} & \\
\hline & 이용자 할 수 있는 일의 명확성 & .121 & .130 & .199 & .863 & .201 & & \\
\hline & 이용자 역할의 적정성 & .206 & .118 & .140 & .851 & .136 & & \\
\hline \multirow{3}{*}{$\begin{array}{c}\text { 정보공유 } \\
\text { 의도 }\end{array}$} & 관련 의견의 게시판 게시 의도 & .137 & .118 & .150 & .104 & .870 & \multirow{3}{*}{.8633} & \\
\hline & 제품 활용 방안 게시판 게시 의도 & .192 & .111 & .255 & .178 & .826 & & \\
\hline & 웹사이트 이용 불만에 대한 게시 & .169 & .223 & .069 & .155 & .796 & & \\
\hline
\end{tabular}

〈그림 1〉 확인적 요인 분석 결과

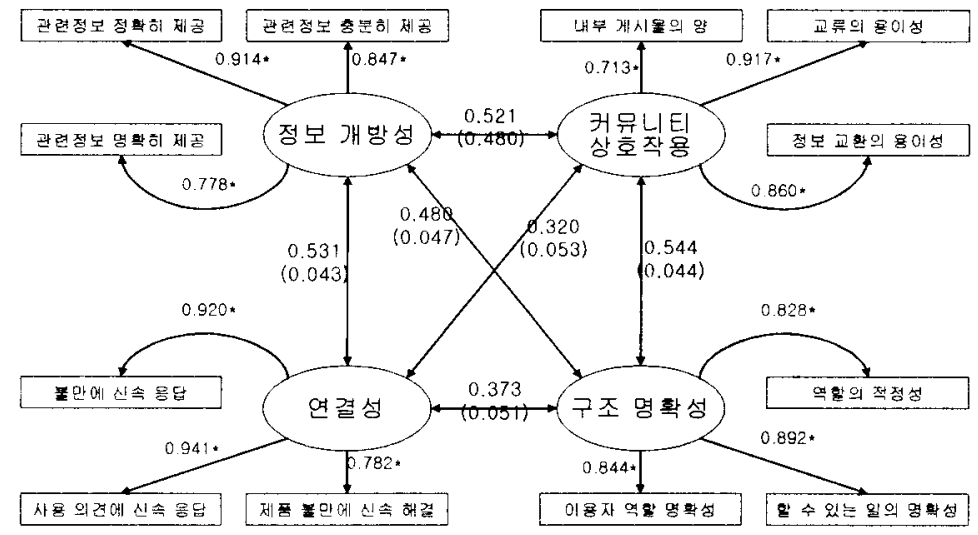

\% 전반적 적합도 지수

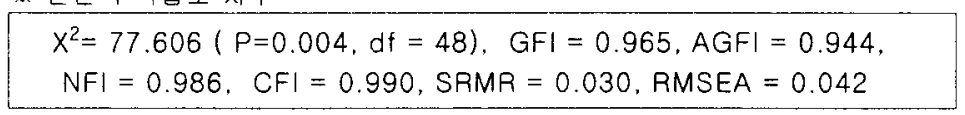

* : $p<.01$, ( ) 안의 수치는 표춘 오차 
〈표 3〉 수렴타당성 분석 결과

\begin{tabular}{|c|c|c|c|c|c|}
\hline 구성개념 & 측정항목 & $\lambda$ 적재량 & $\begin{array}{l}\text { 개별항목 } \\
\text { 신뢰도 }\end{array}$ & $\begin{array}{l}\text { 복합 } \\
\text { 신뢰도 }\end{array}$ & AVE \\
\hline \multirow{3}{*}{$\begin{array}{c}\text { 정보 } \\
\text { 개방성 }\end{array}$} & 관련 정보를 충분히 제공 & $0.847^{*}$ & 0.717 & \multirow{3}{*}{0.884} & \multirow{3}{*}{0.719} \\
\hline & 관련 정보를 정확히 제공 & $0.914^{*}$ & 0.835 & & \\
\hline & 관련 정보를 명확하게 제공 & $0.778^{*}$ & 0.605 & & \\
\hline \multirow{3}{*}{ 연 결 성 } & 이용 불만에 운영자 신속 응답 & $0.920^{*}$ & 0.846 & \multirow{3}{*}{0.914} & \multirow{3}{*}{0.781} \\
\hline & 의견에 운영자 신속 응답 & $0.941^{*}$ & 0.885 & & \\
\hline & 제품 불만에 운영자 신속 해결 & $0.782^{*}$ & 0.612 & & \\
\hline \multirow{3}{*}{$\begin{array}{l}\text { 커뮤니티 } \\
\text { 상호작용 }\end{array}$} & 이용자간 정보 교환 용이성 & $0.860^{*}$ & 0.740 & \multirow{3}{*}{0.872} & \multirow{3}{*}{0.696} \\
\hline & 이용자간 교류 용이성 & $0.917^{*}$ & 0.841 & & \\
\hline & 커뮤니터 내부 게시물의 양 & $0.713^{*}$ & 0.508 & & \\
\hline \multirow{3}{*}{$\begin{array}{c}\text { 구조 } \\
\text { 명확성 }\end{array}$} & 이용자 역할의 명확성 & $0.844^{*}$ & 0.712 & \multirow{3}{*}{0.891} & \multirow{3}{*}{0.73} \\
\hline & 이용자 할 수 있는 일의 명확성 & $0.892^{*}$ & 0.796 & & \\
\hline & 이용자 역할의 적정성 & $0.828^{*}$ & 0.686 & & \\
\hline \multirow{3}{*}{$\begin{array}{c}\text { 정보공유 } \\
\text { 의도 }\end{array}$} & 관련 의견의 게시판 게시 의도 & $0.828^{*}$ & 0.686 & \multirow{3}{*}{0.866} & \multirow{3}{*}{0.684} \\
\hline & 제품 활용 방안 게시판 게시 의도 & $0.898^{*}$ & 0.806 & & \\
\hline & 웹사이트 이용 불만에 대한 게시 & $0.749^{*}$ & 0.561 & & \\
\hline
\end{tabular}

${ }^{*} \mathrm{P}<0.001$

해 $\lambda$ 적재량에 대한 $\mathrm{t}$ 값의 유의성과 평균추출 분산(AVE)에 대한 검토를 통해 평가하였다 (Fornell and Larcker 1981). 분석 결과는 〈그 림 1)과 〈표 3〉과 같다.

〈표 3〉에서 보는 바와 같이 측정항목들과 해당 구성개념들을 연결하는 계수 $\left(\lambda_{x}\right)$ 는 모두 통계적으로 유의하여 측정항목의 수렴타당성을 확인할 수 있었으며 $\mathrm{AVE}$ 값도 만족스런 수준 으로 나타났다. 또한, 〈표 3〉에 나타난 각 구성 개념의 AVE가 〈그림 1)에서 볼 수 있는 구성 개념간의 상관계수의 제곱 값보다 높은 것으로 나타나 판별타당성의 충족 여부를 확인하였다 (Fornell and Larcker 1981).

\section{6 연구가설의 검증}

본 연구에서는 연구의 신뢰도를 높이기 위하 여 연구대상이 되는 구성개념을 복수 항목들 로 측정하고. 이들간의 관계를 검증하기 위하여 Amos 4.0을 이용하여 공변량구조모형(covariance structure modeling)분석을 실시하였다. 공변량 구조모형 분석은 종래의 상관분석, 회귀분석, 경로분석이 가지는 가정을 버리고 보다 현실적 인 상황에서 변수들간의 분석을 가능하게 하는 방법으로서, 기존의 요인 분석과 회귀분석이 결 합된 형태의 분석방법이라고 할 수 있다(김계 수 2001: 이순묵 1990). 
연구1의 가설에 대한 공변량 구조 분석 모형 의 결과는 〈그림 2)와 같다. 〈그림 2)에서 보여 주는 것과 같이 모형의 전반적 적합도 지수는 만족스런 수준을 보여주고 있다고 할 수 있다. 모든 가설과 관계된 경로계수 값은 유의한 것 으로 나타나 모든 가설은 지지되어, 가설과 같 이 정보 개방성. 연결성, 커뮤니티 상호작용성, 구조명확성은 모두 고객의 정보 공유 의도를 높이는 것으로 나타났다. 이에 따라 각각의 가 설들의 결과를 살펴보면 다음과 같다.

가설 1: 디지털 환경 특성으로서의 정보 개방 성과 고객의 정보 공유 의도에 대한 가설을 나타내는 경로계수의 t값은 3.059로 유의하게 나타났다. 따라서 가설 1 은 채택되었다.

가설 2: 디지털 환경 특성으로서의 연결성과 고객의 정보 공유 의도에 대한 가설 을 나타내는 경로계수의 t값은 2.683
로 유의하게 나타났다. 따라서 가설 2는 채택되었다.

가설 3: 디지털 환경 특성으로서의 공동체 상 호작용성과 고객의 정보 공유 의도에 대한 가설을 나타내는 경로계수의 $\mathrm{t}$ 값은 3.305로 유의하게 나타났다. 따 라서 가설 3 은 채택되었다.

가설 4: 디지털 환경 특성으로서의 구조 명 확성과 고객의 정보 공유 의도에 대 한 가설을 나타내는 경로계수의 $\mathrm{t}$ 값 은 2.791로 유의하게 나타났다. 따라 서 가설 4 는 채택되었다.

또한, 응답자들이 쇼핑몰 웹사이트 $(\mathrm{N}=242)$ 와 정보 중심 웹사이트(기업 및 정보 제공 웹 사이트, $\mathrm{N}=110$ )를 선택한 것에 따른 차이 여 부를 분석해 본 결과 웹사이트 선택에 따라 다 른 경로계수를 가지도록 한 모형과 웹사이트의 종류와 관계없이 같은 경로계수를 가지도록한

〈그림 2〉디지털 인프라 특성의 정보적 참여 영향 모형 실증 결과

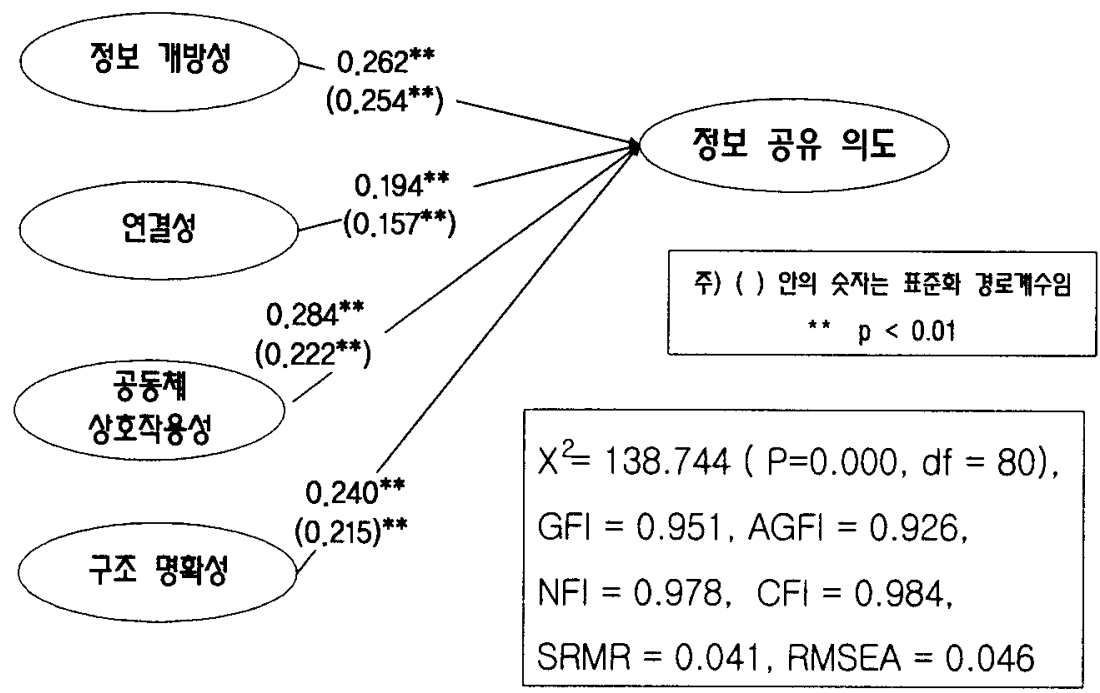


제약 모형 사이에 차이가 없는 것으로 나타나 응답자들이 선정한 웹사이트의 종류는 결과에 영향을 미치지 않음 또한 확인하였다.

\section{IV. 실증 연구 2: 고객의 관계 주도 행위의 형성 과정에 관한 연구}

\section{1 연구 가설의 설정}

이미 소비자가 기업보다 앞서 나가며 구매력 올 바탕으로 기업에게 자신이 필요한 것을 요구 하는 리버스 마케팅의 현상을 이제는 쉽게 찾아 볼 수 있게 되었으며, 적극적인 고객 참여 형태 인 리버스 마케팅의 활성화로 인하여 근간적인 기업과 소비자간의 관계의 틀을 바꾸어 놓을 정 도로 발전하고 있다(Seybold 2002). 그러나. 이 미 논의된 것과 마찬가지로 개뼐적인 소비자가 리버스 마케팅을 한다는 것은 매우 어려운 일이 며, 이러한 문제 때문에 과거에는 주로 산업재 에서 리버스 마케팅에 대한 연구가 진행되었다. 소비자들의 리버스 마케팅 활동은 디지털 환경 뿐만 아니라 일정한 수요를 이루기 위한 가상 커뮤니티를 그 전제로 할 수밖에 없다. 하지만, 가상 커뮤니티의 존재 자체만으로는 고객들이 리버스 마케텅을 전개하려는 것을 설명하기 어 렵다. 가상 커뮤니티는 기업같이 강제력을 가진 조직이 아닌 경우가 대부분이기 때문이다. 따라 서, 리버스 마케팅의 전제조건인 체계적이고 장 기적인 기획이나 높은 수준의 지식 교육 등 (Biemans and Brand 1995)이 이루어지기에는
매우 불안정한 조직이라고 할 수 있다.

객관적으로 강제력을 가진 확고한 조직이 아 님에도 불구하고, 고객들이 커뮤니티를 기반으 로 리버스 마케팅을 전개해 나가는 것은 고객 커뮤니티의 객관적 측면보다는, 커뮤니티가 리 버스 마케팅을 주도하는 고객 스스로를 뒷받침 해줄 수 있다는 주관적 믿음에 기초한다고 볼 수 있다. 이러한 주관적 믿음에 대한 현상을 잘 설명해 주는 개념이 바로 집단 효능감(group efficacy)이라고 볼 수 있다.

효능감(efficacy)은 소유하고 있는 지식이나 기술, 능력이 특정 과업을 수행함에 있어 성공 적인 결과를 초래할 수 있을 것이라는 신념 혹 은 믿음을 의미하며. 개인, 집단, 조직, 혹은 국 가의 각 차원에 적용될 수 있다(Bandura 1982: Gist 1992). 커뮤니티 환경에서 이러한 효능감 은 집단에 대한 믿음인 집단 효능감으로 설명 될 수 있다. 집단 효능감은 효과적으로 일을 처 리해 낼 수 있다고 하는 집단의 믿음으로 정의 되며(최장호 2000), 과거의 연구를 살펴보았을 때 집단 효능감은 집단 내 개인의 행동과 성과 를 예측하는데 있어서 중요한 지표라고 할 수 있다. Bulger(1997)는 효능감을 고객들이 참여 행위를 하는데 있어서 주요한 매개 변수로 보 기도 하였다. 따라서. 집단 효능감은 최근 커뮤 니티 내에서 개인들이 여러 가지 방법으로 제 조업자에게 가격, 제품 사양 등을 요구하는 현 상이 왜 일어나고 있는지를 설명해 주는 개념 이라고 볼 수 있다. 이러한 논의를 바탕으로 기 존 기업과의 관계 변화를 일으키는 리버스 마 케팅 활동의 바탕에는 바로 집단에 대한 주관 적 믿음, 즉 집단 효능감이 매개변수로 작용하 고 있음을 가설화 할 수 있다. 
가설 5: 집단 효능감이 높아질수록 리버스 마케팅 의도는 높아질 것이다.

오프라인 커뮤니티와 달리 디지털 인프라를 통한 가상 커뮤니티의 특징은 정보가 쉅게 축 적되어 모두가 활용할 수 있게 된다는 점이다. 과거 구두로 대화를 하던 것과는 매우 다른 모 습이라고 할 수 있다. 물론, 고객들은 커뮤니티 내에 축적된 정보를 실제로 모두 기억하지는 않는다. 이러한 정보들의 존재는 고객들로 하여 금 커뮤니티 게시판 등을 통하여 자신이 기억 한 정보 뿐만 아니라, 자신이 커뮤니티 내에서 언제든지 검색하고 또 다른 고객들에게 질문하 여 답을 얻을 수 있다는 신념을 형성할 뿐이다. 이에 대하여 Piccoli et al.(2001)은 디지털 환경 에서 온라인 커뮤니티, 혹은 다른 사람들의 다 양한 정보의 존재는 효능감(efficacy)을 증가시 킴을 지적하고 있다.

커뮤니티 내의 정보는 크게 두 가지 형태로 나누어 볼 수 있다. 첫 번째는 전통적인 정보라 고 할 수 있는 제품 속성 정보이다. 이는 제품 에 대한 객관적인 정보로서 제품 카테고리 내 에 어떤 특징이나 속성이 존재하는 가에 대한 정보라고 할 수 있다(최낙환, 박소진 2002: 손 용석, 김진한 2004). 이와 더불어 디지털 인프 라를 통해서 활용되고 있는 유용한 정보원으로 사용되고 있는 것은 소비 경험 정보이다. 소비 경험 정보는 제품이나 서비스의 사용에 대한 개인적인 경험을 정보화한 것들 또한 고객들에 게 매우 유용한 정보로 사용된다(Baker et al. 2002; Alba 1987). 이러한 소비 경험 정보는 온라인 커뮤니티, 지식검색 서비스 등에서 보다 활성화되어 나타나고 있는 정보라고 볼 수 있
다. 이러한 논의를 바탕으로 다음 가설을 제안 하였다.

가설 6: 인지하는 제품속성정보수준이 높아질 수록 집단 효능감은 증가할 것이다

가설 7: 인지하는 소비경험정보수준이 높아질 수록 집단 효능감은 증가할 것이다

\section{2 구성개념의 조작적 정의 및 측정}

\subsection{1 제품 속성 정보}

본 연구에서는 커뮤니티 맥락에서의 제품 속 성 정보를 "구성원들에 의해서 디지털 인프라 를 기반으로 하는 커뮤니티 내부에 쌓여 언제 든지 이용 가능하게된 제품 속성과 관련된 정보" 로 조작적으로 정의하였다. 측정 항목은 Flynn, Goldsmith, and Eastman(1996)의 연구를 바탕 으로 하여 "커뮤니티내 회원들에 의한 제품 기 능에 대한 정보의 정확성 정도", "커뮤니티 구 성원들의 제품 속성 정보의 비교가능 정도", "커뮤니티내 유사 제품군의 기능에 대한 정보 의 풍부성 정도"의 3 개 항목을 리커드형 7점 척도 $(1=$ 전혀 그렇지 않다. $4=$ 보통이다. $7=$ 확실히 그렇다)로 측정하였다.

\subsection{2 소비 경험 정보}

본 연구에서는 커뮤니티 맥락에의 소비 경험 정보를 “구성원들에 의하여 디지털 인프라를 기반으로 하는 커뮤니티 내부에 쌓여 언제든지 이용 가능하게된 제품 소비 경험과 관련된 정 보”로 조작적으로 정의하였다. 측정 항목은 
Park, Mothersbaugh, and Feick(1994)의 연구 를 바탕으로 하여 “커뮤니티내 제품 소비 경험 정보의 풍부성 정도”, “커뮤니티내 제품 사용 노하우에 대한 풍부성 정도”, “커뮤니티내 제품 소비 경헙의 용이성 정도"의 3개 항목을 리커 드형 7 점 척도 $(1=$ 전혀 그렇지 않다, $4=$ 보통이 다. $7=$ 확실히 그렇다)로 측정하였다.

\subsection{3 집단효능감}

본 연구에서는 집단 효능감을 “소비자가 디지 털 인프라를 기반으로 하는 커뮤니티를 활용할 수 있게 됨으로서 생성되는 집단 효능감”으로 조작적으로 정의하였다. 측정 항목은 Compeau (1995)의 연구를 바탕으로 하여 “제공하는 안 내서가 따로 없어도, 커뮤니티를 통하여 문제를 해결할 수 있는 정도”, “커뮤니티를 활욘하지 않는 사람들에 비해 문제를 더 잘 해결할 수 있는 정도". "커뮤니티를 활용하지 않는 사람들 에 비해 뛰어난 능력을 지니게 되는 정도"의 3 개 항목을 리커드형 7점 척도(1=전혀 그렇지 않다. $4=$ 보통이다. $7=$ 확실히 그렇다)로 측정 하였다.

\section{2 .4 리버스 마케팅 의도}

본 연구에서는 리버스 마케팅 의도를 "개인 혹은 커뮤니티가 스스로를 중심으로 기업에게 마케팅 활동을 제안하려는 의도"로 조작적으로 정의하였다. 측정 항목은 Sharma and Sheth (2004)의 연구를 바탕으로 하여 "커뮤니티 이 익을 향상시킬 수 있는 의견의 제안 의도", “내 이익을 향상시킬 아이디어의 공급자에게의 제
안 의도”, “디지털 인프라를 통하여 상품 공급 업자에게 제안하는 것의 용이성 정도”의 3 개 항목을 리커드형 7 점 척도 $(1=$ 전혀 그렇지 않 다, $4=$ 보통이다. $7=$ 확실히 그렇다)로 측정하 였다.

\section{3 조사대상 및 자료수집}

디지털 환경이라는 추상적인 상황 설정보다는 보다 구체적으로 설문의 상황을 설정하기 위하 여 최근 방문한 정보나 제품 혹은 소핑몰 관련 커뮤니티를 대상으로 하여 설문 응답을 하도록 하여 실증 연구를 진행하였다. 조사 대상 표본 은 디지털 인프라 환경에서 선도적인 소비자 행동을 보이고 있는 20대 중심의 대학생 및 대 학원생, 직장인을 중심으로 하는 젊은 층에 국 한하였다. 설문지는 총 468 부가 배부되었고 그 중 부의 설문지 336 부가 회수되었다. 이들 가운 데서 응답이 부실한 표본 15 개를 제외하고 총 321 개의 표본을 최종분석에 사용하였다.

\section{4 표본의 일반적 특성}

총 321 명의 응답자 중 남성은 141 명 $(43.9 \%)$, 여성은 180 명 $(56.1 \%)$ 으로 구성되었다. 응답 자의 연령은 18 38세까지 분포하였으나 이 중 $87.2 \%$ 가 20대였다.

\section{5 척도의 신뢰성 및 타당성 검증}

\section{5 .1 척도의 신뢰성 검증}

신뢰성과 타당성의 개괄적 판단을 위해 요인 
〈표 4〉 탐험적 요인 분석 및 신뢰성 분석 결과

\begin{tabular}{|c|c|c|c|c|c|c|c|}
\hline $\begin{array}{l}\text { 구성 } \\
\text { 개념 }\end{array}$ & 측정항목 & 요인1 & 요인2 & 요인3 & 요인4 & $\begin{array}{l}\text { Alpha } \\
\text { 계수 }\end{array}$ & $\begin{array}{c}\text { 설명된 } \\
\text { 분산 }\end{array}$ \\
\hline 제품 & 속성 정보의 정확성 & .809 & .244 & .277 & 1.59 & \multirow{3}{*}{.8736} & \multirow{12}{*}{$81.433 \%$} \\
\hline 속성 & 속성정보의 풍부성 & .800 & .302 & .266 & .129 & & \\
\hline 정보 & 속성 정보의 비교 가능성 & .802 & .237 & .212 & .156 & & \\
\hline 소비 & 경험 정보의 풍부성 & .338 & .805 & .198 & .180 & \multirow{3}{*}{.9128} & \\
\hline 경험 & 노하우 관련 정보의 풍부성 & .263 & .865 & .217 & .148 & & \\
\hline 정보 & 경험 정보 검색의 용이성 & .209 & .829 & .345 & .094 & & \\
\hline \multirow{3}{*}{$\begin{array}{c}\text { 집단 } \\
\text { 효능감 }\end{array}$} & 안내서 없이 문제 해결 정도 & .275 & .329 & .741 & .177 & \multirow{3}{*}{.8625} & \\
\hline & 타인 대비 문제 해결 정도 & .245 & .190 & .835 & .230 & & \\
\hline & 보통 이상 문제 해결 정도 & .284 & .283 & .738 & .216 & & \\
\hline \multirow{3}{*}{$\begin{array}{c}\text { 리버스 } \\
\text { 마케팅 } \\
\text { 의도 }\end{array}$} & 커뮤니티 이읙 향상 방안 제안 의도 & .129 & .134 & .192 & .872 & \multirow{3}{*}{.8766} & \\
\hline & 내 이익 항상 방안의 제안 의도 & .058 & .144 & .115 & .895 & & \\
\hline & 제안의 용이성 지각 의도 & .214 & .079 & .200 & .816 & & \\
\hline
\end{tabular}

분석과 Cronbach-a 계수의 측정을 통하여 신뢰도 를 분석하였다. 분석 결과는 〈표 4〉와 같다.

요인분석과 신뢰도 분석 결과 본 연구에서 측 정된 이론변수들은 Cronbach-a 계수값이 모두 0.8 이상으로 나타나 측정항목들이 비교적 신 뢰할 만한 수준에서 측정되었다고 볼 수 있다 (Nunally 1967).

\subsection{2 척도의 타당성 검증}

판별 타당성을 확인하기 위하여 내생 변수군 과 외생 변수군에 대한 확인적 요인분석을 실 시하였으며, 수렴 타당성의 판단을 위해 $\lambda$ 적재 량에 대한 $\mathrm{t}$ 값의 유의성과 평균추출분산(AVE) 에 대한 검토를 통해 평가하였다(Fornell and

〈그림 3〉 외생변수군의 확인적 요인 분석 결과
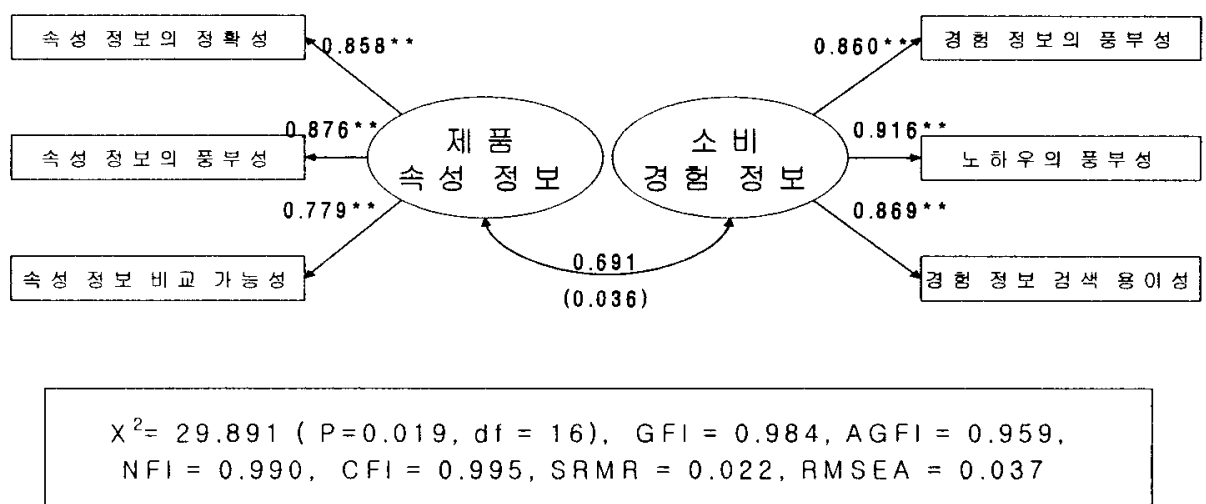

* : p<.01, () 안의 수치는 표준 오치 
Larcker 1981). 분석 결과는 〈그림 3〉, 〈그림 4〉와 〈표 5〉와 같다.

〈표 5〉에서 보는 바와 같이 측정항목들과 해 당 구성개념들을 연결하는 계수 $\left(\lambda_{x}\right)$ 는 모두
통계적으로 유의하여 측정항목의 수렴타당성을 확인할 수 있었으며 AVE 값도 만족스런 수준 으로 나타났다. 또한, 〈표 5>에 나타난 각 구성 개념의 AVE가 〈그림 3)과 〈그림 4〉에서 볼

〈그림 4〉 내생변수군의 확인적 요인 분석 결과

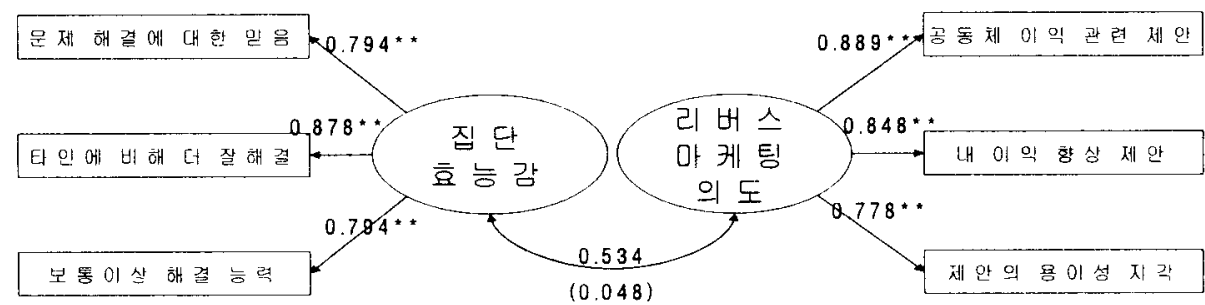

$X^{2}=29.256(P=0.022, d f=16) . \quad G F I=0.985, A G F I=0.961$.

$N F I=0.986, \quad C F I=0.994, S R M R=0.028$. RMSEA $=0.036$

* : p <.01, () 안의 수치는 표준 오차

〈표 5〉 수렴타당성 분석 결과

\begin{tabular}{|c|c|c|c|c|c|}
\hline 구성개념 & 측정항목 & $\lambda$ 적재량 & $\begin{array}{l}\text { 개별항목 } \\
\text { 신뢰도 }\end{array}$ & $\begin{array}{l}\text { 복합 } \\
\text { 신뢰도 }\end{array}$ & AVE \\
\hline \multirow{3}{*}{$\begin{array}{l}\text { 제품 } \\
\text { 속성 } \\
\text { 정보 }\end{array}$} & 속성 정보의 정확성 & $0.858^{*}$ & 0.736 & \multirow{3}{*}{0.877} & \multirow{3}{*}{0.703} \\
\hline & 속성정보의 풍부성 & $0.876^{*}$ & 0.767 & & \\
\hline & 속성 정보의 비교 가능성 & $0.779^{*}$ & 0.607 & & \\
\hline \multirow{3}{*}{$\begin{array}{l}\text { 소비 } \\
\text { 경험 } \\
\text { 정보 }\end{array}$} & 경험 정보의 풍부성 & $0.860^{*}$ & 0.740 & \multirow{3}{*}{0.913} & \multirow{3}{*}{0.778} \\
\hline & 노하우 관련 정보의 풍부성 & $0.916^{*}$ & 0.839 & & \\
\hline & 경험 정보 검색의 용이성 & $0.869^{*}$ & 0.755 & & \\
\hline \multirow{3}{*}{$\begin{array}{l}\text { 집단 } \\
\text { 효능감 }\end{array}$} & 안내서가 없어도 문제를 해결할 수 있는 정도 & $0.794^{*}$ & 0.630 & \multirow{3}{*}{0.863} & \multirow{3}{*}{0.677} \\
\hline & $\begin{array}{c}\text { 다른 사람에 비해서 문제를 더 잘 해결할 수 } \\
\text { 있는 정도 }\end{array}$ & $0.878^{*}$ & 0.771 & & \\
\hline & $\begin{array}{c}\text { 보통이상의 문제 해결 능력을 가지고 있다고 } \\
\text { 지각하는 정도 }\end{array}$ & $0.794^{*}$ & 0.630 & & \\
\hline \multirow{3}{*}{$\begin{array}{c}\text { 리버스 } \\
\text { 마케 팅 } \\
\text { 의도 }\end{array}$} & 커뮤니터 이익 향상 방안의 제안 정도 & $0.889^{*}$ & 0.789 & \multirow{3}{*}{0.877} & \multirow{3}{*}{0.705} \\
\hline & 내 이익 향상 방안의 제안정도 & $0.848^{*}$ & 0.719 & & \\
\hline & 제안의 용이성 지각 정도 & $0.778^{*}$ & 0.608 & & \\
\hline
\end{tabular}

${ }^{*} \mathrm{P}<0.001$ 
수 있는 구성 개념간의 상관계수의 제곱 값보 다 높은 것으로 나타나 판별타당성의 충족 여 부를 확인하였다(Fornell and Larcker 1981).

\section{6 연구가설의 검증}

연구가설을 검증하기 위하여 실증연구 1 과 마 찬가지로 Amos 4.0을 이용하여 공변량구조모 형(covariance structure modeling) 분석을 실시 하였다. 실증 연구2의 가설에 대한 공변량구조 분석 모형의 결과는 〈그림 5)와 같다.

〈그림 5〉에서와 같이 모형의 전반적 적합도 지수는 만족스런 수준을 보여주고 있다. 모든 가설과 관계된 경로계수 값은 유의한 것으로 나타나 모든 가설은 지지었다. 가설과 같이 제 품 속성 정보와 소비 경험 정보는 집단 효능감 에 영향을 미치며, 집단 효능감은 적극적 고객 참여 행위로 볼 수 있는 리버스 마케팅 의도에 영향을 미치는 것으로 나타났다. 각각의 가설들 의 결과를 살펴보면 다음과 같다.
가설 5: 집단 효능감과 고객의 리버스 마케팅 에 대한 가설을 나타내는 경로계수 값은 0.618 이며 $\mathrm{t}$ 값은 8.878 로 계수 값이 유의적임을 알 수 있다. 따라서 가설 5 는 채택되었다. 하지만, 제품 속성정보와 소비 경험 정보가 리버스 마케팅 의도에 바로 영향을 미칠 가 능성에 대한 문제 또한 제기될 수 있 다. 제품 속성 정보와 소비 경험 정 보가 리버스 마케팅 의도에 직접적인 영향을 미칠 가능성을 염두에 두고 모형을 구성하여 이에 대한 가능성을 검토해 보았으며. 그 결과를 〈그림 6>에 나타내었다.

이러한 가능성의 분석결과 제품 속 성 정보와 리버스 마케팅 의도 간의 직접 영향에 대한 경로계수 값은 0.064 이며 t값은 0.564 로 유의하지 않 은 것으로 나타났다. 또한, 소비 경험 정보와 리버스 마케팅 의도간의 직접 영향에 대한 경로계수 값은 0.022 이

〈그림 5〉 가설 검증 결과

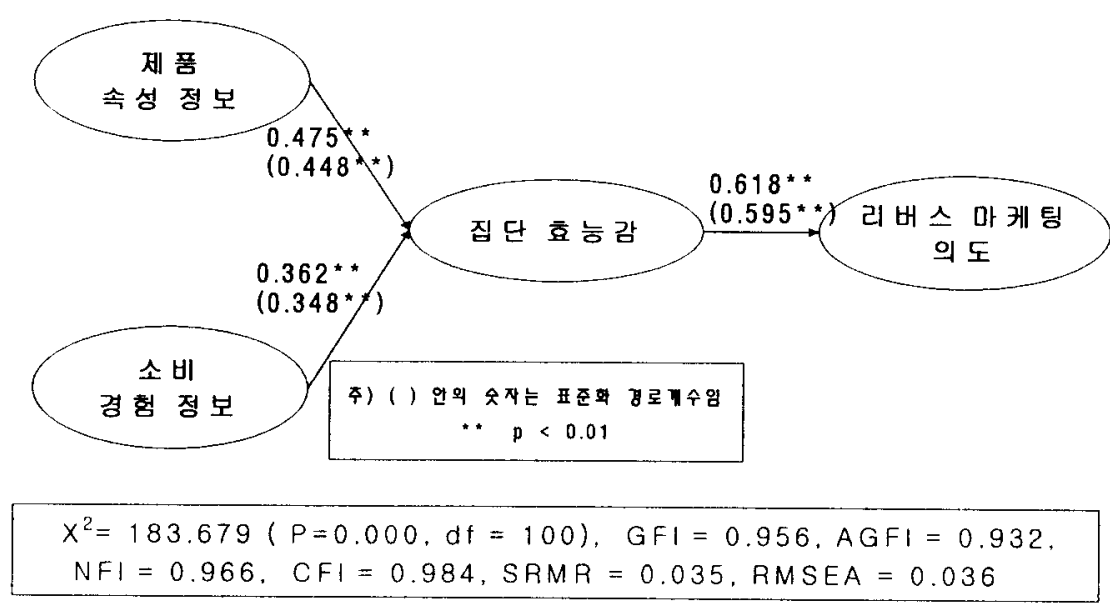


〈그림 6〉 제품 속성 정보와 소비 경험 정보의 직접 영향 모형 및 검증

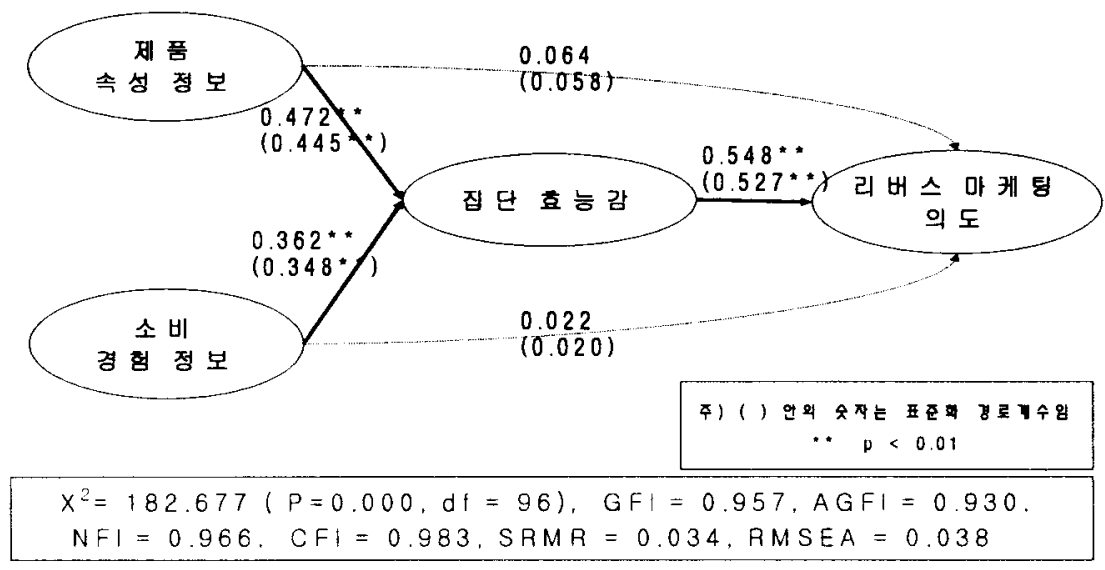

며 t값은 0.219 로 유의하지 않은 것 으로 나타났다.

가설 6: 제품 속성 정보와 고객의 집단 효능 감에 대한 가설을 나타내는 경로계 수 값은 0.475 이며 t값은 6.607로 계 수 값이 유의적임을 알 수 있다. 따 라서 가설 6 은 채택되었다.

가설 7: 소비 경험 정보와 고객의 집단 효능 감에 대한 가설을 나타내는 경로계 수 값은 0.362 이며 $\mathrm{t}$ 값은 5.432 로 계 수 값이 유의적임을 알 수 있다. 따 라서 가설 7 은 채택되었다.

\section{V. 종합적 토의 및 시사점}

\section{1. 연구결과의 요약}

본 연구는 디지털 환경에서 고객 참여가 급격 하게 활성화된 이유를 밝히기 위하여 디지털
환경에서의 고객의 소극적 참여 형태인 정보 공유가 어떤 디지털 환경의 요인에 의해서 촉 진되었는지를 이론적인 검토와 실증 연구를 통 하여 살펴보았다. 또한, 디지털 환경 속에서 일 어나고 있는 고객들의 리버스 마케팅 현상을 커뮤니티를 기반으로 한 연구2를 통하여 살펴 보고 있다. 연구2에서는 커뮤니티를 기반으로 한 고객들의 정보 공유 활동이 리버스 마케팅 으로 이어지고 있음을 보여주고 있다.

연구의 결과 디지털 환경은 그 특성으로 인하 여 고객들의 정보 공유 활동을 활성화시킬 수 있었으며, 이러한 정보 공유로 인한 디지털 환 경 내 정보의 축적은 커뮤니티에 기반하고 있 는 고객들에게 있어서 집단 효능감을 매개로 적극적인 고객 참여 행동인 리버스 마케팅 의 도로 이어질 수 있음을 실증하였다. 연구의 결 과를 요약하면 〈그림 7〉과 같다.

이 두 연구를 통하여 디지털 환경 하에서 정 보 공유로 정의된 고객 참여가 활발하게 되었 는지에 대한 이유를 밝혔을 뿐 아니라. 기존의 기업에 있어서 긍정적인 촉면으로 비추어 졌던 


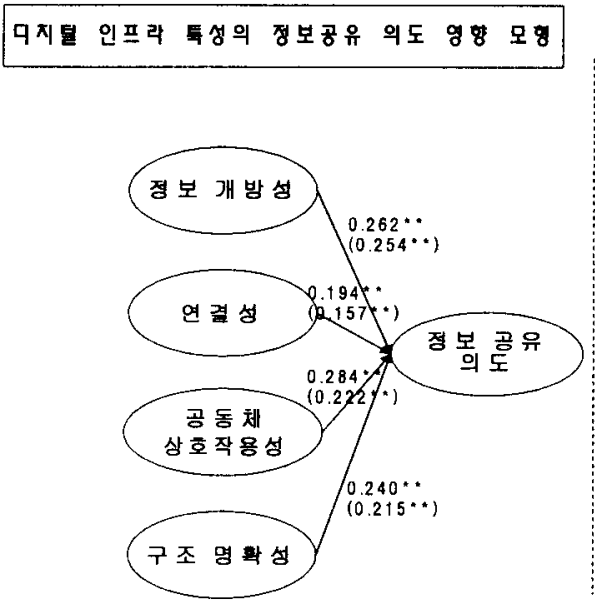

축적된 정보의 리버스마케항 의도 영형 모형

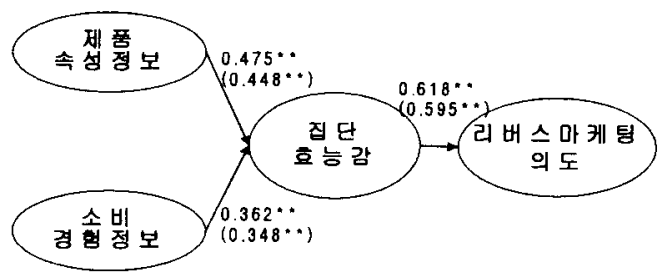

주) ( ) 연의 숫재는 표준화 경로수수임 ** $\mathbf{p}<0.01$

이러한 고객 정보 공유 활동의 결과가 커뮤니 티 내에 축적되고 있다는 것이 기업에게 고객기업과의 관계 변화라는 또 다른 의미로 다가 갈 수 있음을 시사하였다.

이러한 연구 결과는 기존의 기업 주도적이었 던 고객-기업 간의 관계가 디지털 환경의 도입 과 가상 커뮤니티의 보편화로 인하여 향후 고 객 주도적인 관계로 변화할 수 있음을 시사하 고 있다고 할 수 있다.

\section{2 연구의 시사점}

본 연구에서는 디지털 환경 하에서 활성화되 고 있는 고객 참여 행동의 형성 과정을 설명하 기 위하여 디지털 인프라 특성이 고객의 정보 공유 행동에 미치는 영향과 정보 공유 행동으 로 인하여 축적된 정보가 고객 주도적인 마케 팅 활동인 리버스 마케팅 의도의 형성에 이르 는 개념적인 틀을 형성하고, 모형을 개발하였으 며 실증분석을 통하여 이를 검증하였다. 본 연

구의 이론적 시사점은 다음과 같다.

첫째, 고객의 소극적 참여 행동인 정보 공유 에 영향을 미치는 디지털 환경 측면의 특성 요 인을 규명하였다. 과거에도 디지털 환경이 고객 의 마케팅 프로세스에의 참여에 긍정적인 영향 을 미친다는 지적은 있었으나 대부분 개념적 수준에서의 지적이었으며, 구체적이며 실증적인 연구는 매우 미흡하였다. 본 연구에서는 고객의 마케팅 프로세스에의 참여를 저해했던 요인을 극복하게 하여주는 디지털 인프라 특성 요인을 규명하여, 디지털 인프라의 어떠한 톡성들로 인 하여 고객 참여가 활성화되고 있는지에 대하여 규명하였다.

둘째, 디지털 환경에서 리버스 마케팅 활동의 형성 과정을 밝혔다. 이를 통하여 향후 디지털 환경 내에서 고객 주도적 마케팅 활동이 보편 적 현상이 될 수 있음을 제시하여, 새로운 마케 팅 환경에 대한 이해를 넓히는데 기여하였다.

셋째, 고객 주도적 마케팅 활동에 대한 대응 연구가 필요함을 제시하였다. 디지털 인프라와 
커뮤니티의 발달에 따라 정보 공유나 리버스 마케팅 활동은 보다 확대 될 것이나, 이러한 고 객의 주도적 관계 형성 행동들이 보편화된 이 후의 소비자의 행동에 대한 연구는 매우 미흡 한 편이다. 새롭게 형성된 고객 주도적 관계 형 성 행동 속에서 새롭게 나타나는 여러 가지 소 비자 행동과 적절한 기업의 대응 전략에 대한 연구의 필요성을 제시하였다.

본 연구의 전략적 시사점은 다음과 같다.

첫째, 본 연구에서는 Hagel III and Armstrong (1997)이 주장했던 역시장(reverse market)이 디지털 환경 내에서 보편화 될 것임을 실증하 였다. 디지털 인프라의 보급은 기업에게 있어서 기존과는 완전히 다른 고객과의 관계 형성을 의미함을 제시하고 있다. 과거 기업들은 주도적 으로 고객들에게 마케팅 활동을 펼쳤으나. 이제 는 하나의 협력자로서 고객과의 관계를 가져가 는 것이 리버스 마케팅에 대한 고객 욕구를 활 용할 수 있는 길임을 시사하였다.

둘째, 디지털 환경에서의 고객 행동에 대한 기업의 이해를 넓혔다. 본 연구에서는 고객의 효율적인 참여를 이끌어 낼 수 있는 방안을 디 지털 환경 특성 요인적 측면에서 제시하고 있 다. 과거 기업들은 자신들의 성과를 높이기 위 하여 커뮤니터 등을 포함하는 웹사이트들을 구 축하여 고객의 다양한 정보를 활용하고자 하였 으나 많은 기업들이 계획했던 성과를 올리지 못하였다. 고객 정보를 이끌어 내어 활용하기 위해서는 고객의 정보 공유 행동에 미치는 디 지털 인프라의 특성 요인을 웹사이트 등의 설 계에 할용할 필요가 있으며. 고객의 보다 적극 적인 참여를 이끌어 내기 위해서는 기존의 기 업들이 제공했던 제품 속성 정보와 함께 소비
경험 정보의 제공이 매우 중요한 요인임을 본 연구에서는 지적하고 있다.

마지막으로 고객의 마케팅 주도 행위가 일어 날 수 있는 산업을 추정하여 볼 수 있다. 고객 의 적극적 마케팅 활동에의 참여는 정보를 기 반으로 한다. 따라서, 고객이 충분한 정보를 가 질 수 있는 경우에 고객의 마케팅 주도 행위가 보다 활성화 될 것으로 보인다. 따라서, 고객이 커뮤니티를 형성하고 지식공유를 위해서 노력 하는 산업이나 혹은 고객의 소비 경험 지식이 제품의 평가나 구매에 중요한 역할을 하는 상 품군에 대해서 보다 고객의 주도적 관계 형성 행동이 활성화 될 것을 예측하여 볼 수 있다. 만약 자사의 상품군이 이에 해당되는 경우라면 보다 적극적인 고객 참여 대응 전략을 수립해 야 할 것이다.

\section{VI. 연구의 한계 및 향후 연구 과제}

\section{1 연구의 한계}

본 연구는 디지털 환경 하에서 고객 주도적 마케팅이라는 소비자 행위에 대한 탐색적 연 구의 성격을 가지고 있어 여러 한계를 지니고 있다.

첫째, 연구 내용에 대한 선행 연구의 부족으 로 이론 변수간의 관계에 대한 이론적 근거가 건고하지 못하다. 고객 주도적인 마케팅 활동에 대한 연구의 틀이 매우 부족한 상태에서 이전 의 기업 주도적 마케팅 활동의 툴에서 연구되 었던 변수와 이론적 근거를 사용하여 가설 근 
거 등을 도출하였으나. 향후 고객 주도적 마케 팅 활동에 대한 지속적인 연구를 통하여 이론 적 토대를 강화시켜나갈 필요성이 있다.

둘째, 연구 모형이 가지는 한계점으로서 본 연구 모형에서는 혁신 성향, 통제 성향 등의 소 비자 톡성 변수나 제품 관여도 등의 소비자 행 동 관련 변수들, 상황 요인들을 모형에 포함시 키지 못하였다.

셋째, 본 연구는 20 대를 중심으로 실증 연구 표본이 한정되었다는 점이다. 본 연구의 목적이 고객들의 참여를 중심으로 연구하는 것이어서, 현재 디지털 인프라에 익숙하며 쉽게 참여할 수 있는 계층인 20대를 중심으로 표본을 구성 하였다. 이런 측면은 본 연구의 실증 분석 결과 를 일반화시키는데 한계점이 될 수 있다고 할 수 있다.

\section{2 향후 연구과제}

고객 주도적 관계로 변화하고 있다는 본 논문 의 결과는 향후 많은 연구과제를 안겨주고 있 다고 할 수 있다. 기존의 마케팅 관련 연구들은 기업 주도적 관계라는 틀을 가정하고 연구된 것들이라고 할 수 있다. 이 기본적인 틀을 바꾸 어 놓고 본다면 기존의 많은 마케팅 이론들을 재검토할 필요성이 발생하게 된다.

첫째, 기존에 연구되었던 마케팅 프로세스를 새로운 시각으로 바라보아야 할 필요성이 제기 된다. 고객의 주도적 참여행동이 보편화된다고 한다면, 예를 들어 기존의 연결 마케팅에 있어 서 중요한 과제였던 "가치 있는 고객의 발굴" 이라는 개념을 바꾸어 놓을 수도 있다. 주로 연 결 마케팅에서 논의되어온 가치 있는 고객은
높은 매출이나 자사의 이익이 높은 상품을 구 매하는 사람이라는 관점을 가지고 있음을 찾아 볼 수 있다(황병일 1999: 김병도 2004). 하지 만, 고객 참여 프로그램에 의한 연결관계의 구 축은 기존 상품의 이익률이나 매출뿐만 아니라, 참여를 통하여 기업의 전반적인 비용을 줄여줄 수 있는 고객 또한 “적합한” 고객이 될 수 있 음을 보여줄 수 있다. 다른 예를 본다면, 마케 팅에서의 STP 과정도 다시 검토할 필요성 또 한 제기될 수도 있다. 고객의 주도적 참여가 보 편화 된다면 세분화(segmentation)가 아닌 커 뮤니티 등을 통한 군집화(aggrigation)가, 목표 시장의 선정(targeting)보다는 내 상품과 관련 된 커뮤니티와의 연결(connecting)이 더 중요한 마케팅의 개념으로 자리잡을 수도 있다.

둘째, 고객 주도적 행위가 보편화된 마케팅 환경 하에서는 기업에게 새로운 마케팅 시스템 및 조직에 대한 연구가 필요함을 제기하여 볼 수 있다. Ploskina(2001)는 고객의 적극적인 참 여를 통하여 새로운 관계를 구축하고 관리하는 것이 고객과 기업의 효용을 모두 늘릴 수 있다 고 주장하며, 기업은 고객이 기업과의 관계를 관리할 수 있는 방법을 제시하는 것이 중요하 다고 제안하고 있다. 만약 고객의 집단화된 참 여를 활용할 수 있다면, 기업은 탐색/실패 비용 이 감소하며, 부가 서비스 개발이 용이(Hagel III and Armstrong 1997)하게 되는 등의 많은 이점을 가질 수 있게 된다. 그러나. 고객의 집 단화된 참여를 활용하기 위해서는 고객 참여의 폭과 깊이를 효과적으로 넓혀줄 수 있도록 기 업 내부의 마케팅 프로세스를 변화시켜주는 것 이 필요하다. 고객들이 직접 참여하여 쉽게 고 객 스스로를 위한 성과를 낼 수 있도록 다양화 
된 고객 접점을 고객 참여 모듈로 재설계 하여 야 하며 기업의 내부 프로세스는 고객들이 하 는 행위의 인프라로서의 성격을 가져야 할 것 이다. 하지만 이러한 원칙들이 어떤 방법으로 현실화 될 수 있는지에 대하여는 많은 연구가 필요할 것으로 보인다.

본 연구는 디지털 시대의 고객 행동의 변화에 따른 기업-고객과의 관계 변화가 현실화되고 있음을 보여주고 있다. 이는 향후 고객이 관계 의 주도권을 가져가고자 노력하는 시대에는 기 업의 마케팅 시스템이 어떻게 바뀌어야 할지에 대한 많은 연구들의 필요성을 제기하고 있다고 할 수 있다.

〈논문 접수일: 2005. 09. 29〉 〈게재 확정일: 2006. 02. 13〉

\section{참고문헌}

강명수(2002), "온라인 커뮤니터 특성이 몰입과 성과에 미치는 영향에 관한 연구: 경제적 거래 수행을 중심으로," 서울대학교 대학원 박사학위 논문.

김계수(2001), AMOS 구조방정식 모형 분석, 서

울, SPSS아카데미.

김병도(2004), 코카콜라는 어떻게 산타에게 빨

간 옷을 입혔는가. 서울: 21세기북스. 김학윤, 이호배(2002), "사이트특성과 고객애호 도의 관계: 몰입의 매개를 중심으로." 한국 마케팅학회 하계 경영통합 학술대회 발표논 문집.

김현식(2004), "온라인 정보중간상의 서비스 역
량과 고개정보 보호의 성실성에 대한 게임 이론적 모형 개발," 서울대학교 대학원 박 사학위 논문.

민승규(2001), "사고는 반드시 일어난다는 사고

를," 기업나라(웹진), 11 월.

손용석, 김진한(2004), "사전지식의 역할에 대한 탐색적 연구 및 지식기반 접근법의 제안: 소비자의 하이테크 제품 평가과정을 중심으 로," 한국마케팅 학회 춘계 학술대회 발표 논문집.

송창석(1996), "가상환경에서의 연결 마케팅에 관한 연구." 서울대학교 대학원 박사학위 논문.

이동일(2000). "인터넷 역시장 형성과정에서 정 보중간상 역할에 대한 연구: 집단상가 입점 업체의 참여의도를 중심으로," 서울대학교 대학원 박사학위 논문.

이두희(1999), 인터넷 마케팅, 서울: 청아 출판사. 이문규(2002), "e-SERVQUAL:인터넷 서비스

품질의 소비자 평가 측정 도구," 마케팅연 구, 17(1), 73-95.

이순묵(1990), 공변량구조분석, 서울: 성원사. 이은영(2004), "온라인 구성 수용과 확산 경로에 대한 이중경로 모형에 관한 연구," 서울대 학교 대학원 박사학위 논문.

이태민(2003), "모바일 환경에서 상호작용성의 구성요인이 구매의도에 미치는 영향에 관한 연구," 서울대학교 대학원 박사학위 논문. 임종원, 이동일(2002), “디지덜 환경하의 유통경 로 변화," 서울대학교 경영대학 전자상거래 지원센터 연구논문.

임 홍(2004), "고객 참여환경특성이 사이트 로 열티에 미치는 영향에 관한 연구," 서울대 
학교 대학원 석사학위 논문.

조호현(1996), "마케팅 시스템 관계화에 관한 연

구: 정보기술의 영향을 중심으로," 서울대

학교 대학원 박사학위 논문.

주우진, 김재범(2002), “인터넷 마케팅," 경문

사: 서울.

최낙환, 박소진(2002), “정보형태에 따른 정보수

용에 대한 개인주의/집단주의 성향의 호

과," 한국마케팅저널, 4(1), 25-54.

최장호(2000), "집단효능감 지각의 영향요인과

결과에 대한 연구." 서울대학교 대학원 경

영학과 석사학위 논문.

황병일(1999), "마케팅 사고의 변천과 마케팅 커

뮤니케이션: 관계 마케팅 관점," 산학경영

연구, 12, 1-27.

Alba, Joseph W. and J. Wesley Hutchinson (1987). "Dimensions of Consumer Expertise," Journal of Consumer Research, 13, 411-454.

Baker, Julie., Parasuraman A., Dhruv Grewal, and Voss Clenn B.(2002), "The Influence of Multiple Store Environment Cues on Perceived Merchandise Value and Patronage Intentions," Journal of Marketing, 66(April), 120-141.

Bandura, A.(1982), "Self-efficacy mechanism in human agency," American Psychologist. 37(2), 122-147.

Berthon, Pierre and Leyland F Pitt(1996). "The World Wide Web as an Advertising Medium: Toward an Understanding of Conversion Efficiency," Journal of Advertising Research, 36(1), 43-54.

Bettencourt, L.A.(1997), "Customer Voluntary performance: customers as partners in service delivery," Journal of retailing, Vol73(1), 383-406.

Biemans, Wim. G and Maryse J. Brand(1995), "Reverse Marketing: A Synergy of Purchasing and Relationship Marketing," International Journal of Purchasing and Materials Management, 31(3), 29-37.

Bitner, Mary Jo., Willian T. Franda, Amy R. Hubbert and Valarie A. Zeithaml(1997), "Customer contricutions and roles in service delivery," International Journal of Service Industry Management, 8(3), 193-205.

Bowen, David. E(1986), "Managing customers as huan resources in service organisations," Human Resource Management, Vol25(3). 371-383.

Bowen, David E., and Gareth R. Jones(1986), "Transaction Cost Analysis of Service Organization-Customer Exchange," Academy of Management Review, 11(2), 428-441.

Bulger, Carrie A. and Steven Mellor, "SelfEfficacy as a Mediator of the Relationship Between Perceived Union Barriers and Women's Participation in Union Activities," Joumal of Applied Psychology, 82(6), 935-944. Choi, Tohmas(1999), "Reverse Marketign in Asia: A Korean Experience," Business $\mathrm{Ho}^{-}$ rizons, 99(Sep-Oct), 34-40.

Compeau, Deborah R and Christopher A. Higgins (1995), "Computer Self-Efficacy: Development of a Measure and Initial Test," MIS Quarterly, 19(2), 189-210. 
Fitzsimmons, James A.(1985), "Consumer Participation and Productivity in Service Operations," Interfaces, 15(3), 60-67.

Flynn, Leisa Reinecke, Goldsmith, Ronald E., and Eastman, Jacqueline K.(1996), "Opinion Leaders and Opinion Seekers: Two New Measurement Scales," Journal of the Academy of Marketing Science, 24(2), 137-147.

Fornell, Claes and David F. Larcker(1981), "Evaluating Structureal Equation Models with Unobservable Variables and Measurement Error," Joumal of Marketing Research, $39-50$.

Gist. M. E.(1992), "Self-efficacy: A Theoretical analysis of its determinants and malleability." Academy of Management Review. 17(2), 183-211.

Glazer, Rashi(1991), "Marketing in an InformationIntensive Environment: Strategic Implications of Knowledge as an Asset," Journal of Marketing, 55(4), 1-19.

Goodwin, Cathy(1988), "I Can Do It Myself: Training the Service Consumer to Contribute," The Journal of Service Marketing, 2(4), 71-78.

Hagel, John III and Arthur G. Armstrong(1997), "Net Gain: Expanding Markets through Virtual Communities," HBS Press.

Harris. Kim. Richard Harris, and Steve Baron (2001) "Customer Participation in retail service: Lessons from Brecht," International Journal of Retail \& Distribution Management. 29(8). 359-369.
Holland, Jonna. and Stacey Menzel Baker(2001). "Customer Participation in Creating Site Brand Loyalty," Journal of Interactive marketing 15/4(Autumn), 34-45.

Keh, Hean Tat and Chi Wei Teo(2001), "Retail Customers as Partial employees in service provision: a conceptual framework," International Journal of Retail \& Distribution Management, 29(8), 370-378.

Kellog, Deborah L., William E. Youngdahl, and David E. Bowen(1997) "On the relationship between customer participation and satisfaction: two framework," International Joumal of Service Industry Management, 8(3). 206-219.

Larsson, Rikard. and David E. Bowen(1989), "Organization and Custumer:Managing Design and Coordination of Services," Academy of Management, 14(2), 213-233. Leenders, M.R. and Blenkhorn, D.L.(1988), Reverse Marketing: The New Buyer-Supplier Relationship, New York, The Free Press. Lovelock, Christopher H. and Robert F. Young (1979), "Look to Consumers to Increase Productivity," Harvard Business Review, 57(May-June), 168-178.

Menon. Ajay., Bernard J. Jaworski, and Ajay K. Kohli(1997), "Product Quality: Impact of Interdepartmental Interactions," Academy of Marketing Science Journal, 25(3), 187-198. Merilees. Bill and Dale Miller(2001), "Superstore Interactivity: a new self-service paradigm of retail service?." International Journal of 
Retail \& Distribution Management, Vol.29 (8), 379-389.

Miller. Katherine I. and Peter R. Monge(1986), "Participation, Satisfaction, and Productivity: A Meta-Analytic Review," Academy of Management Journal, 29(4), 727-753.

Mills, Peter K. and James H. Morris(1986), "Clients as 'Partial' Employees of Service Organizations: Role Development in Client participation," The Academy of Management Review, 11(4), 726-735.

Mills, Peter K., Richard B. Chase, and Newton Margulies(1983), "Motivating the Client/ Employee System as a Service Production Strategy," The Academy of Management Review. 8(2), 301-10.

Newman Jr.. Peter James(2003), An investigation of consumer reactions to negative wordof-mouth on the internet, Doctoral Dissertation, University of Illinois.

Nunnally, Jun C.(1967). Psychometric Theory, New-York. McGraw-Hill.

Park, C. Whan, Mothersbaugh, David L.. and Feick Lawrence(1994), "Consumer knowledge assessment," Journal of Consumer Research. 21(1), p71-82,

Piccoli, Gabriele, Rami Ahmad, and Blake Ives (2001). "Web-based virtual learning environments: A research framewark and a preliminary assessment of effectiveness in basic it skills training," MIS Quarterly. 25(4), 401-426.
Ploskina, Brian(2001), "When Customers manage the Relationship," Interactive Week. May/ 21/2001.

Seybold, Patricia(2002), Customer Revolution, New York. Crown Business.

Sharma, Arun and Jagdish N. Sheth(2004). "Web-based marketing: The coming revolution in marketing thought and strategy," Journal of Business Research, 57, 696-702. Song, Jae H. and Carl R. Adams(1993), "Differentiation Through Customer Involvement in Production or Delivery," Journal of Consumer Marketing, 10(2), 4-12.

Thomke, stefan and Eric von Hippel(2002). "Customers as Innovators: A New way to Create Value," Harvard Business Review, 80(4), 74-81.

Watson, Rechard T., Pierre Berthon, Leyland F. Pitt, and George M. Zinkhan(2000), ELECTRONIC COMMERCE, Harcourt INC.

Wind, Jerry. and Arvind Rangaswamy(2001), "Customerization: The Next Revolution in Mass Customization," Journal of Interactive Marketing. 15/1(Winter), 13-32.

Yao, Dong-Qing, Xjaohang Yue. Xiaoyin Wang. and John J.Liu(2005), "The impact of information sharing on a returns policy with the addition of a direct channel," International Joumal of Production Economics, 97, 196-209.

Zeithaml, Valari. and Bitner, M.J.(1996), Services Marketing, New York, McGraw-Hill. 


\title{
An Exploratory study on the Effect of Digital Environment On Customer Participation and Marketing System
}

\author{
Jong-Won Lim* \\ Suk-Joon Yang**
}

\begin{abstract}
This study explores the effect of the properties of digital infra on customer participation to explain how customers' initiatives impact the marketing process in the digital environment. Also the effect of the accumulated information through customers information sharing on their initiatives in the marketing activities can be discovered. These effects can be better understood by developing comprehensive model and employing large sample empirical test. Studyl identifies the properties of digital infra which overcomes the limitations of off-line environment in customers participation Information openness, connectedness, community interaction and structure clarity - and how these properties activate customers' participation in the marketing process. Study2 shows the process structure of reverse marketing activities in the digital environment. These findings deliver the fact that customers' initiatives in the marketing activities will be accepted generally under the digital environment. Consequently, this study suggests some managerial implications for completely different marketing strategies in response to customers initiatives in the marketing activities under the digital environment.
\end{abstract}

Keywords: customer participation, information sharing, reverse marketing, customer initiatives, customer behavior in digital environment

\footnotetext{
* Professor, College of Business Administration, Seoul National Univ.

${ }^{* *}$ Full-time Lecturer, Department of Business Administration, Kyungsung Univ.
} 